\title{
Fluorescence, pigment and microscopic characterization of Bering Sea phytoplankton community structure and photosynthetic competency in the presence of a Cold Pool during summer
}

\author{
Joaquim I. Goes ${ }^{\text {a,* }}$, Helga do Rosario Gomes ${ }^{\text {a }}$, Elin M. Haugen ${ }^{\mathrm{b}}$, Kali T. McKee ${ }^{\mathrm{a}}$, \\ Eurico J. D'Sa ${ }^{c}$, Alexander M. Chekalyuk ${ }^{a}$, Diane K. Stoecker ${ }^{d}$, Phyllis J. Stabeno ${ }^{e}$, \\ Sei-Ichi Saitoh ${ }^{\mathrm{f}}$, Raymond N. Sambrotto ${ }^{\mathrm{a}}$ \\ ${ }^{a}$ Lamont Doherty Earth Observatory, Columbia University, Palisades, New York, NY 10964, USA \\ b Bigelow Laboratory for Ocean Sciences, East Boothbay Harbor, Maine, ME 04544, USA

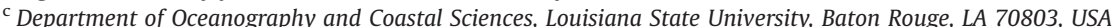 \\ ${ }^{\mathrm{d}}$ University of Maryland Center for Environmental Science, Horn Point Laboratory, Cambridge, MD 21613, USA \\ e NOAA Pacific Marine Environmental Laboratory, 7600 Sand Point Way NE, Seattle, Washington, WA 98115-0070, USA \\ ${ }^{\mathrm{f}}$ Graduate School of Fisheries Sciences, Hokkaido University, 3-1-1 Minato-cho Hakodate, Hokkaido 041-8611, Japan
}

\section{A R T I C L E I N F O}

Keywords:

Bering Sea

Phytoplankton

Taxonomy

Diversity

Sea-ice

Salinity

Temperature

Nutrients

\begin{abstract}
A B S T R A C T
Spectral fluorescence measurements of phytoplankton chlorophyll $a(\mathrm{Chl} a)$, phytoplankton phycobilipigments and variable fluorescence (Fv/Fm), are utilized with High Performance Liquid Chromatography (HPLC) estimates of phytoplankton pigments and microscopic cells counts to construct a comprehensive picture of summer-time phytoplankton communities and their photosynthetic competency in the eastern Bering Sea shelf. Although the Bering Sea was ice-free during our study, the exceptionally cold winter that preceded the summer of 2008 when our cruise took place, facilitated the formation of a "Cold Pool" $\left(<2{ }^{\circ} \mathrm{C}\right)$ and its entrapment at depth in the northern middle shelf. The presence of a strong pycnocline over the entire middle and outer shelves restricted inorganic nutrient fluxes into the surface waters resulting in phytoplankton populations that were photo-physiologically stressed due to nutrient limitation. Elevated Chl $a$ concentrations recorded in the Green Belt along the shelf edge of the Bering Sea, were due to Phaeocystis pouchetii and nano-sized cryptophytes. Although inorganic nutrients were not limiting in the Green Belt, Fv/Fm values were low in all probability due to iron limitation. Phytoplankton communities in the low biomass surface waters of the middle shelf were comprised of prasinophytes, haptophytes, cryptophytes and diatoms. In the northern part of the middle shelf, a sinking bloom made up of the centric diatoms Chaeotoceros socialis, Thalassiosira nordenskioeldii and Porosira glacialis was located above the Cold Pool. The high biomass associated with this senescent bloom and its accretion above the pycnocline, suggests that the Cold Pool acts as a barrier, preventing sinking phytoplankton from reaching the bottom where they can become available to benthic organisms. We further posit that if summer-time storms are not energetic enough and the Cold Pool is not eroded, its presence facilitates the transfer of the large spring phytoplankton bloom to the pelagic ecosystem.
\end{abstract}

(c) 2013 Elsevier Ltd. All rights reserved.

\section{Introduction}

The eastern Bering Sea shelf is one of the most productive marine ecosystems in the world. From an ecosystem perspective, its most defining feature is its highly productive phytoplankton bloom which forms in spring and supports extraordinarily rich stocks of fish, migratory marine birds and mammals (Hunt et al., 2011). Sea food landings from the Bering Sea are extremely large

\footnotetext{
* Corresponding author.

E-mail address: jig@ldeo.columbia.edu (J.I. Goes).
}

and have been estimated to account for more than $10 \%$ of the world's and about 55\% of the U.S. annual seafood harvest (NOAA, 2013).

As with most high-latitude oceanic regions, sea-ice is a key component of the Bering Sea shelf ecosystem. It provides the seed population for the spring bloom and is also responsible for introduction of dissolved iron into the water column which is especially beneficial to the Fe limited High Nutrient Low Chlorophyll (HNLC) waters of the offshore Bering Sea (Aguilar-Islas et al., 2007). Sea-ice also has a huge impact on the upper ocean circulation processes (Zhang et al., 2012) that aid in the advection of nutrients on to the shelf, and in the release of freshwater from 
sea-ice which affects the static stability of the surface ocean and the formation of thermal structures and fronts on the eastern Bering Sea shelf (Kachel et al., 2002). These fronts which start developing in spring, create three distinct hydro-chemical domains, i.e. the inner-shelf, the middle-shelf and the outer-shelf that have been widely used in describing various aspects of the ecosystem of the eastern Bering Sea shelf (Coachman, 1986; Kachel et al., 2002; Sullivan et al., 2008). Phytoplankton growth over the eastern Bering Sea shelf is restricted to an extremely short season, and generally begins when sea-ice begins to retreat. Although growth occurs over a limited period, it is rapid, and greatly favored by increased stability of the water column induced by sea-ice melt water during cold years and thermal stratification during warm years. With the increase in solar radiation, spring-time phytoplankton are able to take advantage of extremely high concentrations of inorganic nutrients to form massive blooms over the wide expanse of the eastern Bering Sea shelf. In cold years, with significant sea-ice after mid-March, there can be two blooms, an early bloom in March-April, and a second bloom in May or June (Stabeno et al., 2010, 2012a) that can result from stormdriven injections of new nitrogen into the upper-water column (Sambrotto et al., 1986). This largely sea-ice dependent explosive growth of phytoplankton strips the entire Bering Sea shelf water column of all its nutrients in a short time. Since nutrient replenishment by vertical transport from the deep is severely constrained by a strong halocline (Aagaard et al., 1981; Woodgate et al., 2005), further biomass accumulation of phytoplankton in summer, especially in the southeastern Bering Sea is generally restricted (Whitledge et al., 1986; Rho et al., 2005). Summer phytoplankton population photosynthesis and growth are thus largely dependent on cross-shelf advective processes including mesoscale eddies that introduce nutrients on to the shelf (Springer et al., 1996; Mizobata and Saitoh, 2004; Okkonen et al., 2004).

While the areal extent and rate of retreat of sea-ice are important determinants of the magnitude of spring phytoplankton blooms, they can also influence environmental conditions that develop over the Bering Sea shelf in the following summer, such as the formation of the Cold Pool (Zhang et al., 2012; Stabeno et al., 2012a,b) and the degree of stratification (Ladd and Stabeno, 2012). The formation of the Cold Pool or bottom waters with temperatures $<2{ }^{\circ} \mathrm{C}$, is tied to the process of stratification which begins in April or May. Once the water column over the middle shelf of the Bering Sea begins to stratify, the warmer surface waters insulate the bottom water layer from warming as the season progresses. The temperature of the bottom layer depends on sea-ice conditions in winter and the temperature of the water column at the onset of stratification in spring (Stabeno et al., 2002, 2007). In cold years (with extensive sea-ice through April), temperatures in the bottom layer or the Cold Pool usually remain below $2{ }^{\circ} \mathrm{C}$ throughout summer.

Sea-ice conditions over the Bering Sea are extremely sensitive to small changes in wind velocities and air temperatures. Since the Bering Sea comes under the influence of storms and climatic patterns such as ENSO (Overland et al., 2012), PDO, NAO and the AO (Overland et al., 1999), sea-ice conditions can vary greatly over seasonal, annual, interannual and decadal cycles (Stabeno et al., 2001) and influence phytoplankton communities and the food chain of the Bering Sea. A turning point in the cyclical pattern of Bering Sea sea-ice behavior (Stabeno and Overland, 2001; Overland and Stabeno, 2004) was the onset of the El-Niño in 1997 which had a huge impact on the ecosystem. Following this event, the Bering Sea experienced a rapid melt back of its sea-ice (Stabeno et al., 2001). Anomalous cloud-free conditions, increased solar heating, decreased onshore transport of slope water and reduced number of energetic storms (Stabeno et al., 2001) all acting in consonance during that year, contributed to the formation of a warm $\left(\sim 12{ }^{\circ} \mathrm{C}\right)$ and stable water column on the shelf in which few nutrients remained to support diatoms (Egge and Aksnes, 1992). These conditions caused a dramatic switch in phytoplankton populations, with profound effects on the rest of the food chain (Baduini et al., 2001; Stockwell et al., 2001). Diatoms were replaced by coccolithophore (i.e. Emiliana huxleyi) blooms, which occupied almost the entire continental shelf of the Southeastern Bering Sea (Broerse et al., 2003). The warming $\left(\sim 3{ }^{\circ} \mathrm{C}\right)$ trend persisted into the 2000s and was marked by significant decreases in sea-ice concentrations, ice duration, maximum ice extent and large crustacean zooplankton. This warm period was followed from 2008 to 2011 by a series of cold years, characterized by high ice extent, increases in large copepods and euphausiids, and improved recruitment of pollock and cod (Stabeno et al., 2012a,b). No comparable information is available on phytoplankton communities that would have taken place during the transition from a warm to a cold year. Such information is essential if we are to understand the influence of changing sea-ice patterns on the primary producers and the production pathways of organic matter which support the valuable fisheries of this extensive high-latitude continental shelf (Moran et al., 2012; Lomas et al., 2012).

Here we use high-resolution fluorescence-based estimates of phytoplankton chlorophyll $a(\mathrm{Chl} a)$, three spectral types of phycoerythrin (PE) and phytoplankton photosynthetic competency, coupled with microscopy and High Performance Liquid Chromatography (HPLC) measurements of diagnostic pigment biomarkers of phytoplankton groups for detailed characterization of phytoplankton community structure during the summer of 2008 which was characterized by the presence of a Cold Pool. Hydrographic and chemical data obtained during the cruise are utilized to describe the data in relation to the environmental conditions, in particular, in relation to the Cold Pool that prevailed during the summer of 2008.

This study was part of a NASA supported International Polar Year study on the impacts of sea-ice changes on the bio-optical properties of high-latitude oceans, and allowed us to participate in a Bering Sea Ecosystem Study-Bering Sea Integrated Ecosystem Research Program (BEST/BSIERP) cruise in the summer of 2008. Although there was no sea-ice during our study, residual effects of the cold winter were obvious from the presence of a Cold Pool and remnants of low salinity surface water in the northern regions of the eastern Bering Sea shelf. The ecological role of the Cold Pool is significant for higher trophic organisms and fisheries (Stabeno et al., 2012a). While it can obstruct cross shelf migration of subarctic fish (Kotwicki et al., 2005; Ciannelli and Bailey, 2005), it can act as a corridor for migration of Arctic species to the southeastern shelf (Stabeno et al., 2012a,b). The Cold Pool can possibly affect cross shore transport of nutrients, but its overall impacts on biomass and composition of phytoplankton within and outside of the pool remain unknown.

\section{Materials and methods}

The data presented in this study were collected on board the US Coast Guard Cutter Healy from the 1st to 31st July 2008. The cruise was part of the BEST/BSIERP study of the Bering Sea, a partnership project between the US National Science Foundation and the North Pacific Research Board, Alaska. Continuous hydrographic profiles were obtained at 177 oceanographic stations along a cruise track shown in Fig. 1, using a Sea-Bird Electronics ${ }^{\circledR}$ ConductivityTemperature-Depth (CTD) rosette fitted with $12 \times 301$ Niskin bottles. The cruise track in Fig. 1 is overlaid on 16 marine regions recently delineated by the BEST/BSIERP research community based on a large 


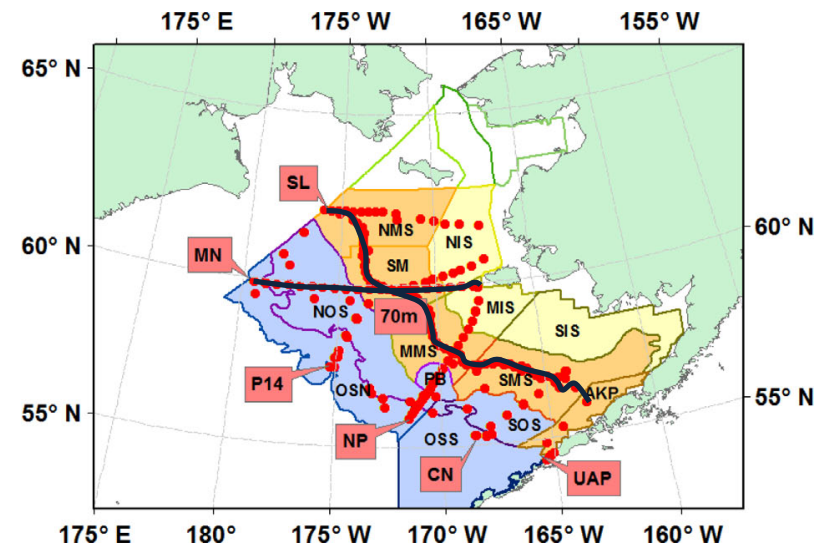

Fig. 1. Cruise track showing CTD station positions along various hydrographic lines occupied during BEST/BSIERP summer cruise of 2008 on board the US Coast Guard Cutter Healy. Stations have been overlaid on the 16 marine regions recently defined by the BSIERP community. A list of full form of the abbreviations for the 16 regions and the rationale for their dilineation is available in Ortiz et al. (2012). Thick lines have been overlaid to show the north-south $70 \mathrm{~m}$ isobath transect and the east-west MN transect.

set of observations of the oceanography, bathymetry, benthic fauna, fish, seabird and marine mammal distribution (Ortiz et al., 2012).

Samples for inorganic nutrients $\left(\mathrm{SiO}_{3}, \mathrm{NO}_{3}+\mathrm{NO}_{2}\right.$ and $\left.\mathrm{PO}_{4}\right)$ were collected directly from Niskin bottles and analyzed immediately on board using a Lachat ${ }^{\circledR}$ QuikChem 8000 flow-injection analyzer (Gordon et al., 1993).

Samples for biological measurements were obtained from six depths, five in the euphotic column that included one from the deep chlorophyll maximum (DCM) and the sixth from below the euphotic depth.

For estimating phytoplankton Chl $a, 250-500 \mathrm{ml}$ of seawater from each of the six depths was filtered in triplicate onto $25 \mathrm{~mm}$ Whatman ${ }^{\circledR} \mathrm{GF} / \mathrm{F}$ filters, which were then placed in $90 \%$ acetone overnight at $-20{ }^{\circ} \mathrm{C}$ for extraction. The pigment was analyzed fluorometrically on-board in a Turner Designs ${ }^{\circledR}$ TD700 fluorometer (Knap et al., 1994). In addition, another set of similarly collected samples at 46 stations was used to estimate a wide spectrum of pigments such as Chl $a, b, c$ and carotenoids using HPLC (Van Heukelem and Thomas, 2001; Hooker et al., 2005). Seawater samples (1-2 l) in duplicate from three depths (surface, DCM and below the euphotic zone) were filtered in duplicate onto $25 \mathrm{~mm}$ Whatman ${ }^{\circledR} \mathrm{GF} / \mathrm{F}$ filters and stored at $80^{\circ} \mathrm{C}$ until analysis. These pigments serve as diagnostic markers of phytoplankton taxa which means that the composition of the phytoplankton community can be evaluated at the same time that Chl $a$ is accurately quantified as a proxy for total biomass estimates.

Phytoplankton taxonomic structure was studied using pigment biomarkers and the matrix factorization program CHEMTAX (Mackey et al., 1996, 1998). Rather than use simple ratios of marker pigments to identify phytoplankton groups, CHEMTAX uses a steepest descent algorithm to fit a matrix of expected pigment ratios for several taxa, to one consisting of the actual pigment ratios from unknown samples. In order to apply CHEMTAX, the heterogeneous data were first binned into three subsets, surface $(0-2 \mathrm{~m})$, mid-depth $(10-33 \mathrm{~m})$ and bottom $(34-75 \mathrm{~m})$. Pigment data (Chl c3, Chl c2, peridinin, 190-butanoyloxyfucoxanthin, fucoxanthin, prasinoxanthin, violaxanthin, 190-hexanoyloxyfucoxanthin, alloxanthin, zeaxanthin, lutein and $\mathrm{Chl} b$ ) from each of these depth bins were then converted into pigment/Chl $a$ ratios. Cluster analysis (Bray Curtis similarity) using PRIMER ${ }^{\circledR}$ ver. 6.1.13 was then performed on $\log (X+1)$ transformed pigment ratios to separate clusters with linkage distances greater than
$70 \%$. CHEMTAX was then applied to the pigment data from each of these clusters to obtain the contribution of eight phytoplankton groups to bulk Chl $a$. These included diatoms, dinoflagellates, chlorophytes, cryptophytes, prasinophytes, haptophyte-6 (indicating E. huxleyi), hapytophyte-8 (indicating Phaeocystis pouchetii) and cyanobacteria. The initial ratio matrix was from Table 6.1 in Higgins et al. (2011). From this initial matrix 29 artificial ratios were randomly generated within a certain range (Wright, personal communication). CHEMTAX was applied to these initial 30 matrices. The output of the matrix with the smallest RMS error was used to generate another 29 artificial ratios that were once again utilized in the subsequent runs which continued until the RMS error became more or less constant. The RMS error values obtained for the surface, mid-depth and bottom were 0.076, 0.045 and 0.042 , respectively.

For microscopic identification and enumeration of phytoplankton, samples were collected in $100 \mathrm{ml}$ screw top hard plastic bottles from 3 depths and at 27 stations (coincident with HPLC pigment analysis). Samples were fixed with $1 \%$ alkaline Lugol's iodine and preserved in $1.5 \%$ buffered formaldehyde solution. The samples were stored under dark and cool conditions and analyzed microscopically within a month of return from the cruise. Phytoplankton cells were allowed to settle overnight in an Ultermohl counting chamber and then counted using a Nikon ${ }^{\circledR}$ inverted microscope at $200 \times$ and $400 \times$ magnifications. The smallest cells enumerated were $\sim 5 \mu \mathrm{m}$ in diameter. Identification was based on standard taxonomic keys (Tomas, 1997). Cryptophytes were identified by epifluorescence microscopy using their yellow-orange fluorescence signatures (Booth, 1993; Macissac and Stockner, 1993).

In addition to the above measurements, seawater samples from 6 depths were analyzed with the recently developed Advanced Laser Fluorometer (ALF) (Chekalyuk and Hafez, 2008). Samples were collected directly from the Niskin samplers into $500 \mathrm{ml}$ acidwashed amber glass bottles, and stored for about $30 \mathrm{~min}$ in the dark at about $5{ }^{\circ} \mathrm{C}$ close to the average seawater temperature of our study area to minimize the impacts of non-photochemical quenching before analysis. Dark adaptation allows all of the PSII reaction centers and electron acceptor molecules of phytoplankton to become fully oxidized and hence available for photochemistry.

The ALF combines high-resolution spectral measurements of blue $(405 \mathrm{~nm})$ and green $(532 \mathrm{~nm})$ laser-stimulated fluorescence with spectral deconvolution techniques to quantify fluorescence of Chl $a$, PE and Chromophoric Dissolved Organic Matter (CDOM) (Chekalyuk and Hafez, 2008; Chekalyuk et al., 2012). All fluorescence values were normalized to water Raman spectra and with the exception of Chl $a$ have been expressed as relative fluorescence units (RFU). RFU values for Chl $a$ were converted into $\mathrm{mg} \mathrm{m}^{-3}$ as described below. The ALF measurements with the blue laser excitation were used for estimating Chl $a$ (peak at $679 \mathrm{~nm}$ ), CDOM (peak at $508 \mathrm{~nm}$ ) and variable fluorescence $(\mathrm{Fv} / \mathrm{Fm})$, whereas the fluorescence measurements with the green laser were used for detection and spectral discrimination of three group-specific types of PE fluorescence. These include PE-1 (peak at $565 \mathrm{~nm}$ fluorescence) from blue water or oligotrophic cyanobacteria with high phycourobilin/phycoerythrobilin (PUB/PEB) ratios, PE-2 (peak at $578 \mathrm{~nm}$ fluorescence) from green water cyanobacteria with low-PUB/PEB ratios that usually thrive in coastal mesohaline waters, and PE-3 (peak at $590 \mathrm{~nm}$ fluorescence) attributable to eukaryotic photoautotrophic cryptophytes (Chekalyuk and Hafez, 2008; Chekalyuk et al., 2012).

Between stations, the ALF was connected to the ship's uncontaminated seawater flow-through system, allowing for continuous in-water fluorescence measurements from approximately $3 \mathrm{~m}$ below the surface. With the exception of a few breaks for reconditioning, the ALF was operated over the entire cruise track 
(Fig. 1), providing almost 95,000 near-real time fluorescence measurements of Chl $a$, CDOM, PE-1, PE-2, PE-3 and Fv/Fm.

For converting Raman-normalized ALF Chl a fluorescence measurements into $\mathrm{mg} \mathrm{m}^{-3}$ units of Chl a concentration, we utilized separate conversion procedures, one for the discrete depth samples and one for the underway flow-through fluorescence measurements. Equation $y=0.347 x^{2}+2.377 x$ derived from a least square regression between the ALF in vivo Chl $a$ fluorescence and HPLC measurements of Chl $a$ concentration (see above; $N=111$; $R^{2}=0.91$ ) were used to convert Raman-normalized Chl $a$ fluorescence into $\mathrm{Chl} a$ concentration ( $\mathrm{mg} \mathrm{m}^{-3}$ ). It may be noted that the intercept was forced to zero during the regression analysis (based on the assumption that zero Chl $a$ should result in zero fluorescence). The regression analysis without forcing the intercept to zero results in the intercept value 0.053 and the equation $y=0.370 x^{2}+2.257 x+0.053 ; R^{2}=0.907$, which corresponds to Chl $a$ concentration $0.053 \mu \mathrm{gl}^{-1}$, or $0.3 \%(=0.053 / 21=0.0025)$ of the range of variability in $\mathrm{Chl} a$ concentration in the data set that we analyzed. The non-linear relationship that we observed between ALF Chl a fluorescence and HPLC Chl $a$ was likely caused by the stronger pigment packaging effect in large diatom cells that dominated the high-Chl $a$ samples at depth and in the northern region. Such a non-linear relationship between $\mathrm{Chl} a$ fluorescence and concentration has been reported in earlier publications (e.g., Chekalyuk et al., 2012)

The ALF underway in vivo Chl $a$ fluorescence and variable fluorescence $(\mathrm{Fv} / \mathrm{Fm})$ measurements, particularly those obtained during the day were affected by solar-induced non-photochemical quenching (NPQ). To eliminate the NPQ effect on the accuracy of Chl $a$ assessments from the underway fluorescence measurements, we used the NPQ-invariant ratios of Raman-normalized Chl $a$ fluorescence to Fv/Fm (Chekalyuk and Hafez, 2011). The conversion equation $y=0.052 x^{2}+0.609 x$, which was derived from regression analysis between these units and HPLC measurements of Chl $a$ concentration in the seawater samples $\left(N=111 ; r^{2}=0.83\right)$, was used for calculation of $\mathrm{Chl} a$ concentration from the ALF underway fluorescence measurements.

A statistically significant relationship $\left(r^{2}=0.86, n=136\right.$, $p<0.001$ ) was also obtained between the Raman corrected PE-3 fluorescence intensities and CHEMTAX-derived estimates of cryptophyte biomass. Fluorescence signatures of PE- 1 and PE- 2 derived by the ALF were relatively low throughout the study period. Although no comparable data on green and blue water cyanobacterial populations was available, PE-1 and PE-2 fluorescence measurements are known to provide good estimates of blue water and green-water cyanobacteria (Chekalyuk et al., 2012; Goes et al., in press). The ALF measurements of variable fluorescence, Fv/Fm reported below were adjusted for non-Chl $a$ background fluorescence as per procedures described in detail in Chekalyuk and Hafez (2008).

\subsection{Inorganic nutrients and dissolved iron amendment experiments}

In order to investigate the roles of inorganic nutrients and dissolved iron as potentially important regulators of summer-time phytoplankton growth in waters above the Bering Sea shelf (Whitledge et al., 1986; Rho et al., 2005) and in the waters of the outer shelf (Aguilar-Islas et al., 2007), respectively, we undertook two iorganic nutrient/dissolved iron enrichment experiments, one with phytoplankton from a shelf station (NP-11) and the other with phytoplankton from an outer shelf or offshore station (P14-4). At the shelf station, inorganic $\mathrm{NO}_{3}$ and $\mathrm{NO}_{2}$ concentrations were below limits of detection and inorganic $\mathrm{PO}_{4}$ and $\mathrm{SiO}_{3}$ were 0.42 , and $7.4 \mu \mathrm{M}$, respectively. At P14-4, inorganic $\mathrm{NO}_{3}, \mathrm{NO}_{2}, \mathrm{PO}_{4}$ and $\mathrm{SiO}_{3}$ concentrations were 3.62, 0.09, 0.69 and $3.13 \mu \mathrm{M}$, respectively. Dissolved iron concentrations were not measured by us, but typical dissolved-Fe concentrations at this time of the year can vary between 0.5 and $4 \mathrm{nmol}^{-1}$ on the shelf, and below detection limits offshore (Aguilar-Islas et al., 2007 and references cited therein).

For our experiments, surface seawater samples were carefully collected in acid cleaned, trace-metal free cubitainers using a Zodiac. In the first experiment, subsamples of water from outer shelf station P14-4 were transferred into 24 trace-metal free acid cleaned polyethylene bags, 8 of which were spiked with $1.5 \mathrm{nmol} \mathrm{l}^{-1}$ concentrations of dissolved iron, and another 8 with $2 \mu \mathrm{M}$ of $\mathrm{NO}_{3}$. A third subset of eight bags with no amendments served as controls. In the second experiment at the on-shelf station NP-11, seawater was transferred into 16 acid-cleaned bags and spiked with $2.7 \mu \mathrm{M}$ of inorganic $\mathrm{NO}_{3}$ and $2 \mu \mathrm{M}$ of $\mathrm{PO}_{4}$. Incubations of the control and treatments were undertaken in an on-deck incubator in which ambient sea-surface temperatures were maintained with running surface seawater.

During Expt 1, 4 bags from each of the treatments and the controls were collected on Day 3 and Day 6 for measurements of Chl $a\left(\mathrm{mg} \mathrm{m}^{-3}\right)$ and at the end of Day 1 and Day 3 in Expt. 2.

A one-way Student $t$-test was used to assess if changes in Chl $a$ within treatments were statistically significant over time of incubation whereas a one-way ANOVA (Holm-Sidak test) was used for assessing differences among treatments. The latter analysis was restricted to samples drawn at the end of the experiments. All statistical tests were performed using Sigmaplot $11^{\circledR}$.

\section{Results}

\subsection{Hydrographic conditions}

In this section, we present an overview of the hydrographic conditions of the eastern Bering Sea in the summer of 2008 using the 16 sub-regions delineated in Ortiz et al. (2012). Additional details of the hydrographic conditions in the Bering Sea during the summer of 2008 are available in Cross et al. (2012); Stabeno et al. (2012a), Moran et al. (2012) and Lomas et al. (2012).

Our data synthesis yielded several noteworthy features which include: (1) sea surface water temperatures in excess of $6{ }^{\circ} \mathrm{C}$ at the surface with the exception of the cold water $\left(1-2{ }^{\circ} \mathrm{C}\right)$ patch on the southeastern side of the Priblof Islands (PB) waters and another $\left(\sim 4{ }^{\circ} \mathrm{C}\right)$ patch around Nunivak Island (Fig. $\left.2 \mathrm{~A}\right),(2)$ a patch of low salinity in the northern middle shelf (NMS) and around St. Michael (SM) Island (Fig. 2B and D), (3) warmer waters over the entire outer shelf (OS) with signs of encroachment of outer shelf and slope waters on to the southern middle (SMS) and inner shelf (SMS) and (4) a Cold Pool distinctly seen in the spatial map at $45 \mathrm{~m}$, north of $59.5^{\circ} \mathrm{N}$ (Fig. 2C). This Cold Pool encompassed the NMS and SM.

The Cold Pool is also clearly visible in the N-S hydrographic section along the $70 \mathrm{~m}$ isobath (Figs. 1 and $3 \mathrm{~A}$ and $\mathrm{B}$ ). Although the vertical section of the $70 \mathrm{~m}$ isobath shows an uniformly warm surface layer (Fig. 3A), two major frontal regions were visible at depth, the first around $57.5^{\circ} \mathrm{N}$ with $\sim 2{ }^{\circ} \mathrm{C}$ waters southwards and the second at $59.5^{\circ} \mathrm{N}$ separating the $<2{ }^{\circ} \mathrm{C}$ Cold Pool waters in the north from the warmer southern $\left(>4^{\circ} \mathrm{C}\right)$ waters. Thus the cross shelf fronts divided the deeper layer of the middle shelf into three broad regions, the southern, the central and the northern regions. Salinity values were clearly higher in the Cold Pool (Fig. 3B), but above the Cold Pool, an entrapped parcel of low salinity waters was observed in the upper $20 \mathrm{~m}$ possibly from spring-time residual melt water or from river runoff.

The distinct hydrographic conditions seen across the shelf are best explained by temperature and salinity profiles along cruise 
(A)

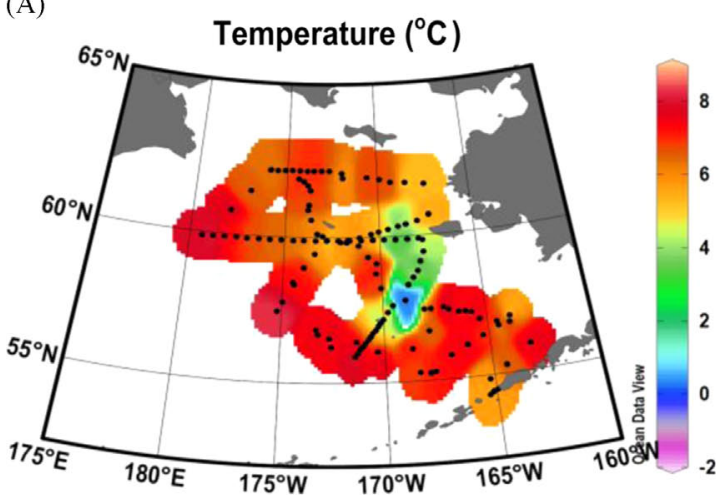

(C)

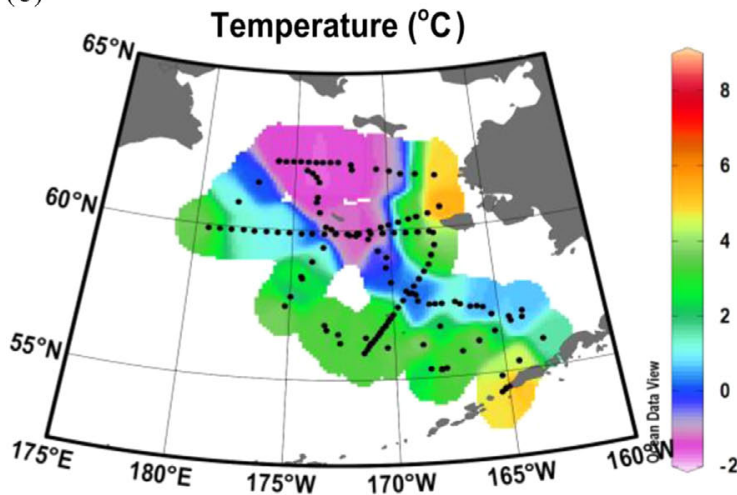

(B)

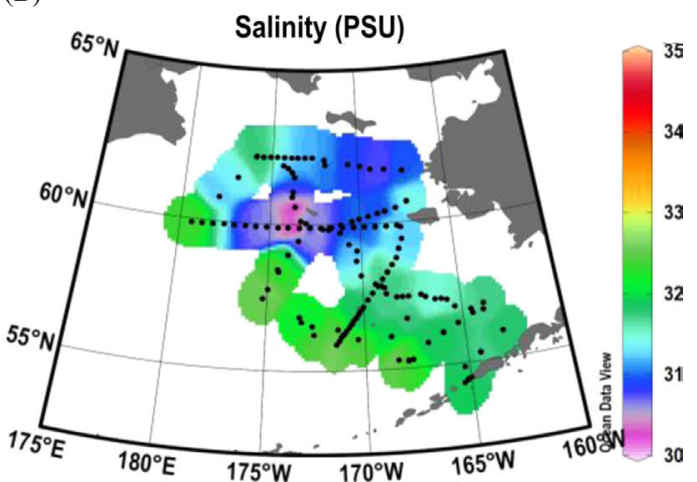

(D)

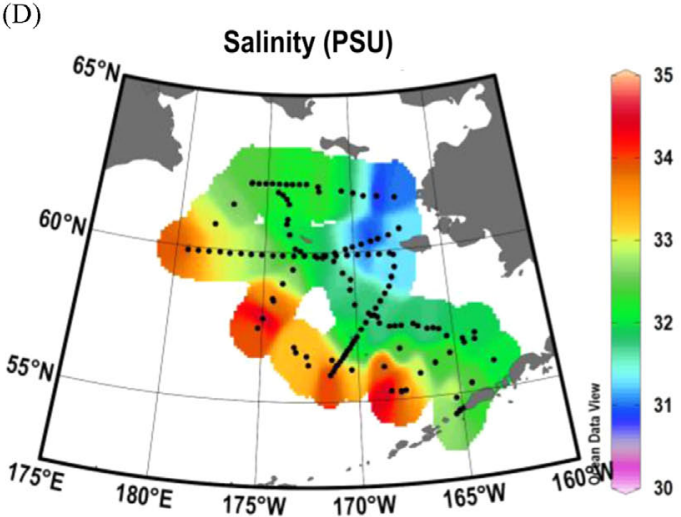

Fig. 2. Spatial distribution of surface $\left(\mathrm{A}\right.$ and $\mathrm{C}$ ) temperature $\left({ }^{\circ} \mathrm{C}\right)$ and $(\mathrm{B}$ and $\mathrm{D})$ salinity (PSU) at the surface and at $35 \mathrm{~m}$ over the study area.

(A)

Temperature $\left({ }^{\circ} \mathrm{C}\right)$

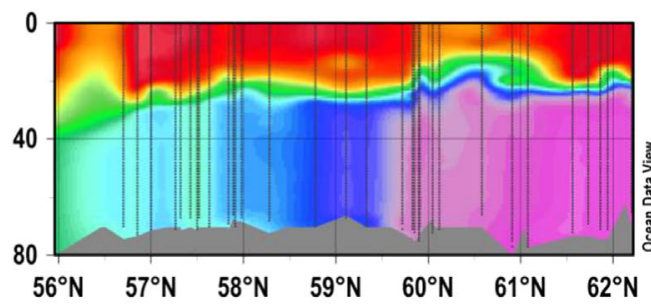

(C)

Temperature $\left({ }^{\circ} \mathrm{C}\right)$

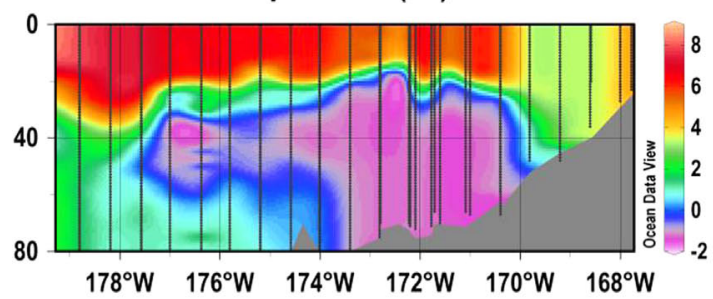

(B)
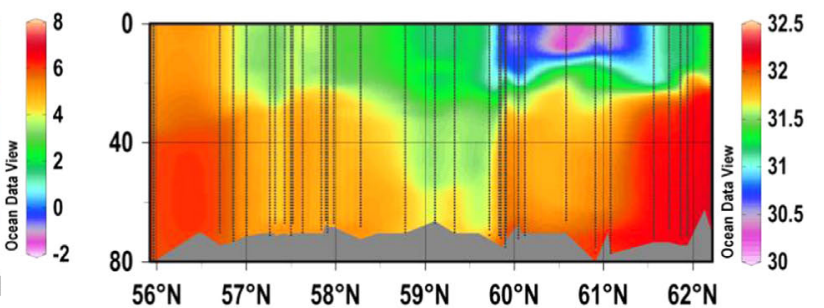

(D)

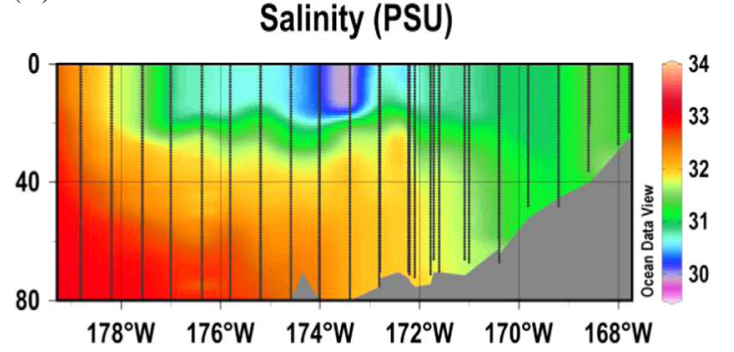

Fig. 3. Vertical sections of (A and C) temperature $\left({ }^{\circ} \mathrm{C}\right)$ and $(\mathrm{B}$ and $\mathrm{D})$ salinity (PSU) along the $70 \mathrm{~m}$ isobath and the $\mathrm{MN}$ line.

line MN (Figs. 1 and 3C and D) which we chose because it represents a section across the shelf where (1) the Cold Pool (located between $178^{\circ}$ and $170^{\circ} \mathrm{W}$ in the middle shelf and extending to the outer shelf) was very prominent and (2) the three well known cross-shelf hydrographic domains, viz. the inner (IS), middle (MS) and the outer (OS) shelves were clearly distinguishable by fronts along the $50 \mathrm{~m}$ (inner front), $80 \mathrm{~m}$ (central front) and along the $100 \mathrm{~m}$ (outer front) isobaths, respectively. The latter front separated the outer shelf from the offshore high salinity waters.
Other noteworthy features that were evident include (1) the three layered structure of the outer shelf, (2) the highly stratified two layered water column of the middle shelf and (3) the coastal tidally well mixed waters eastwards of $170^{\circ} \mathrm{W}$.

\subsection{Inorganic nutrient distribution}

Sea surface inorganic nutrients $\left(\mathrm{PO}_{4}-\mathrm{P}, \mathrm{SiO}_{3}, \mathrm{NO}_{3}-\mathrm{N}\right.$ and $\mathrm{NH}_{4}-\mathrm{N}$ ) were clearly much lower in the eastern Bering Sea shelf 
than offshore (Fig. 4A and D). This was particularly true in the southern inner and middle shelves (SIS and SMS). An eastwest gradient in nutrients visible at the surface was also evident

(A)

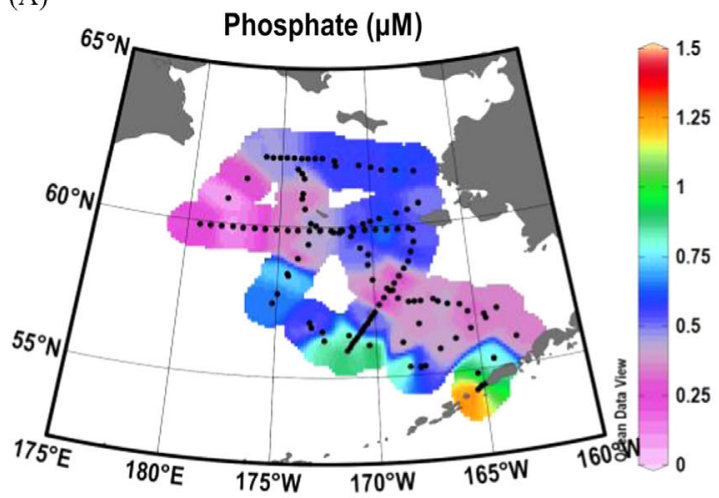

(C)

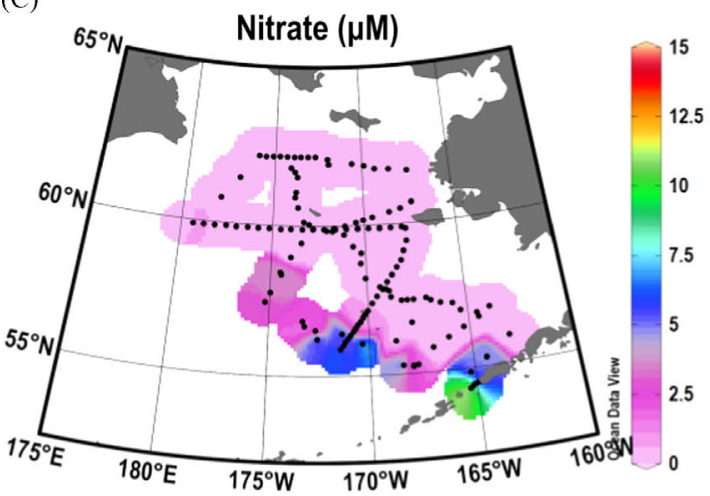

at $35 \mathrm{~m}$, except for $\mathrm{NH}_{4}-\mathrm{N}$ which formed a narrow, highconcentration band along the entire length of the $70 \mathrm{~m}$ isobath (Fig. 5A and D). Offshore, $\mathrm{NH}_{4}-\mathrm{N}$ concentrations were much lower,

(B)

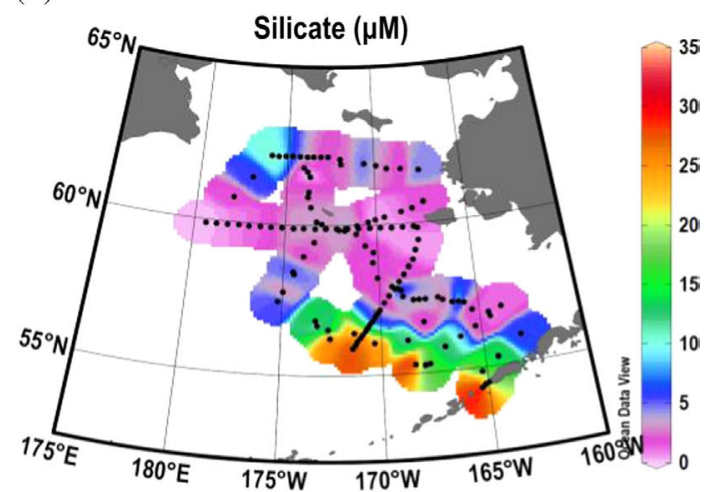

(D)

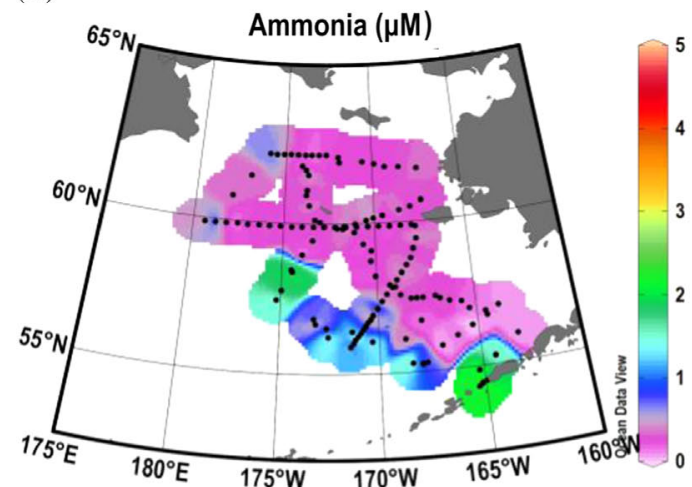

Fig. 4. Spatial distribution of (A) phosphate, (B) silicate, (C) nitrate and (D) ammonia (all expressed in $\mu \mathrm{M}$ ) at the surface over the study area.

(A)

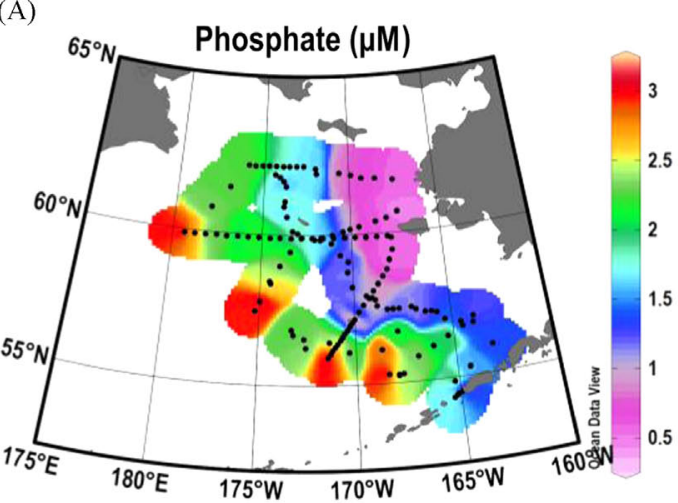

(C)

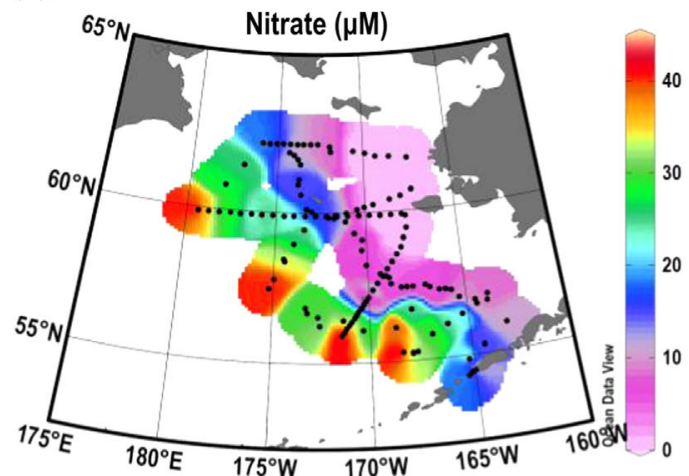

(B)

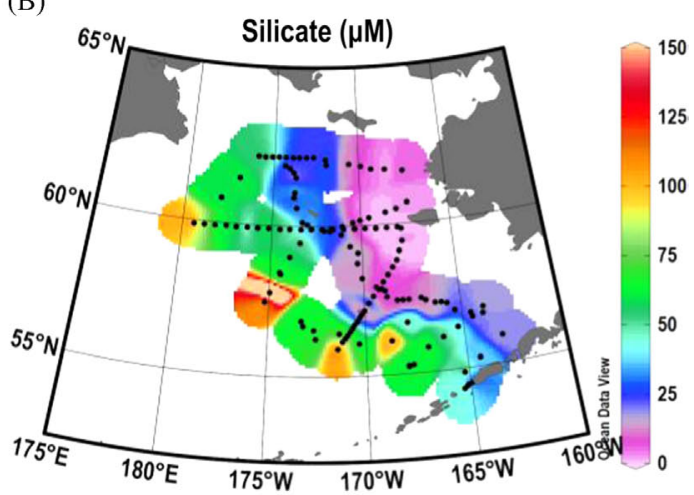

(D)

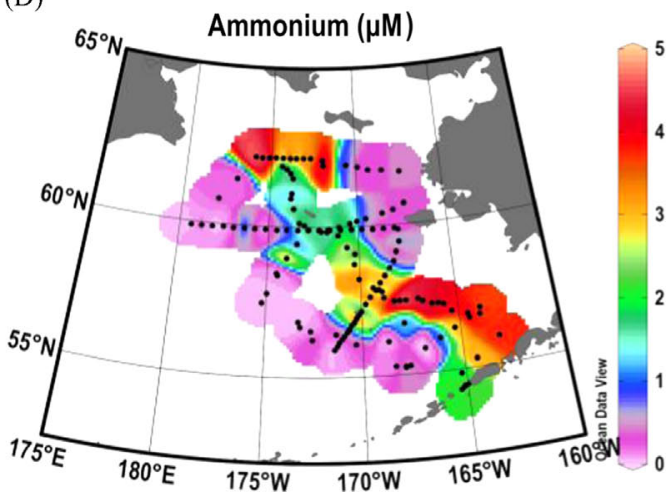

Fig. 5. Spatial distribution of (A) phosphate, (B) silicate, (C) nitrate and (D) ammonia (all expressed in $\mu \mathrm{M}$ ) at $35 \mathrm{~m}$ over the study area. 
indicating the highly localized nature of the regenerative and nitrification processes along the shelf break.

The $\mathrm{N}-\mathrm{S}$ section along the $70 \mathrm{~m}$ isobath showed near depletion of inorganic nutrients in the first $20 \mathrm{~m}$ of the water column along the entire section (Fig. 6A and D). Below this layer, nutrient distribution confirmed that the middle shelf had three regions each with distinct concentrations. Nutrient concentrations within the Cold Pool in the north were much higher with the exception of $\mathrm{NH}_{4}-\mathrm{N}$, whose concentrations tended to be higher southwards (Fig. 6D). The lowest nutrient concentrations were observed in the central section of the middle shelf.

The MN section (Fig. 7A and D) shows the east-west or crossshelf gradient in nutrient distribution with low concentrations throughout the water column in the inner shelf, and a prominent two layered structure in the middle shelf. In the Cold Pool, nutrient concentrations were extremely high, but abruptly transitioned to extremely low levels in the upper surface layer $(0-30 \mathrm{~m})$ above the halocline. Overall nutrient concentrations $\left(\mathrm{PO}_{4}-\mathrm{P}\right.$, $\mathrm{NO}_{3}-\mathrm{N}$ and $\mathrm{SiO}_{3}$ ), were much higher offshore than in the adjacent

(A)

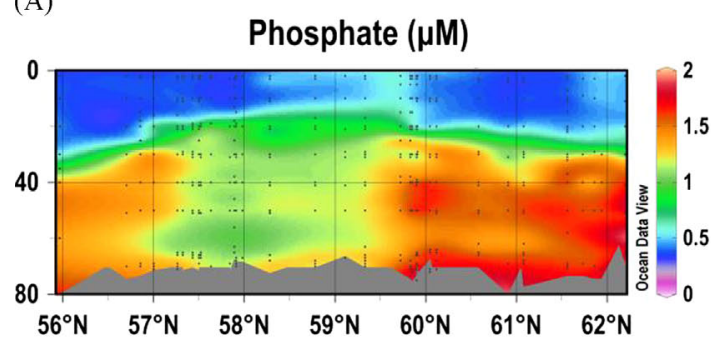

(C)

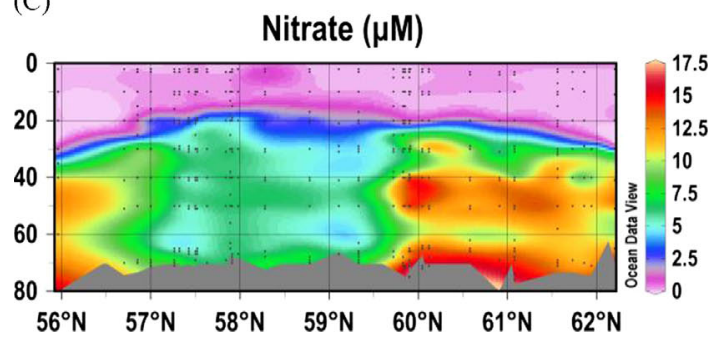

outer shelf. The prominent band of $\mathrm{NH}_{4}-\mathrm{N}$ seen along the shelf break region could be seen as a plume whose origins could be traced to the shallow outer shelf region. Onshore advection of nutrients was not evident along this section but it was much more prominent in the SOS, SMS along sections CN and NP (Fig. 1, data not shown) and westwards of the PB region.

\subsection{Spatial fluorescence patterns}

The high resolution underway fluorescence data collected by the ALF provides a comprehensive picture of the spatial patterns of sea surface Chl $a$ (expressed as $\mathrm{mg} \mathrm{m}^{-3}$ ), phycobilipigments and Fv/Fm (Fig. 8A and E) which would not have been possible with discrete sampling alone. In general, the ALF dataset showed that surface Chl $a$ concentrations were very low throughout the eastern Bering Sea shelf but confirmed the elevated Chl $a$ in the Green Belt (Fig. 8A), a persistent band of high phytoplankton biomass and productivity observed along the shelf edge of the Bering Sea (Springer et al., 1996; Aguilar-Islas et al., 2007). Moderately high

(B)

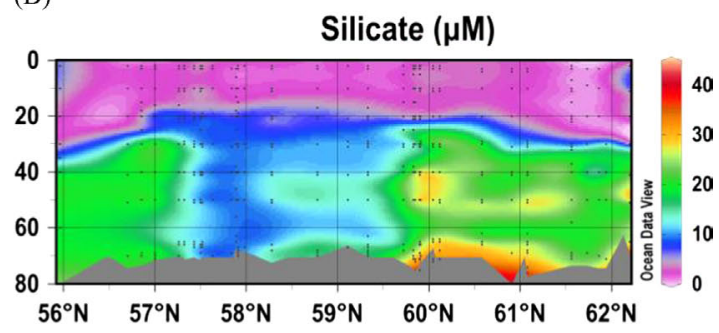

(D)

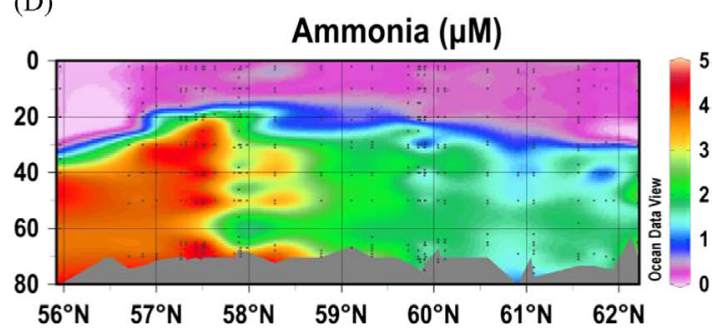

Fig. 6. Vertical sections of (A) phosphate, (B) silicate, (C) nitrate and (D) ammonia (all expressed in $\mu \mathrm{M}$ ) along the $70 \mathrm{~m}$ isobath.

(A)

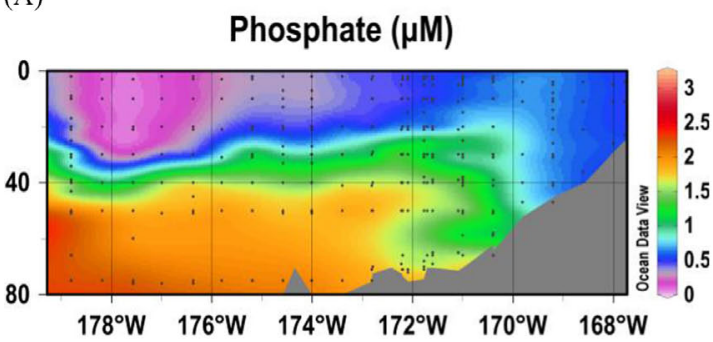

(C)

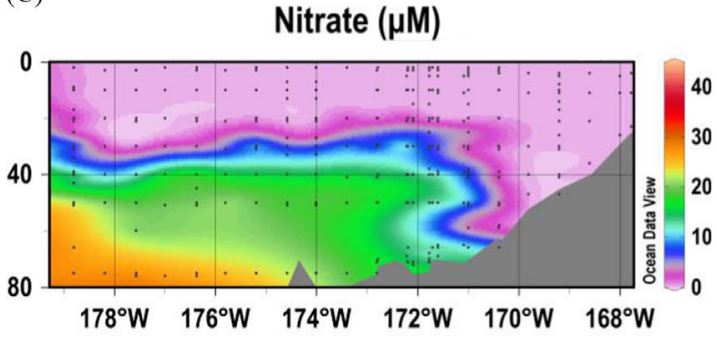

(B)

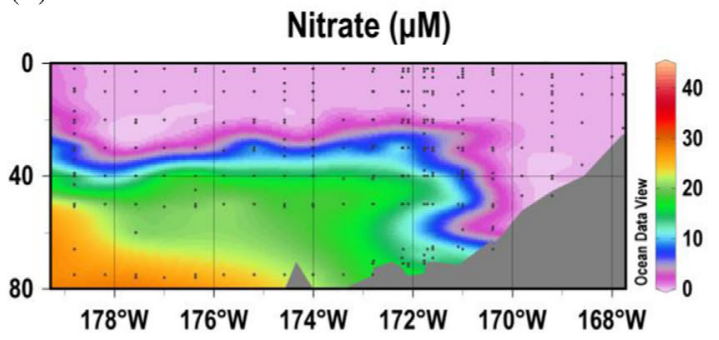

(D)

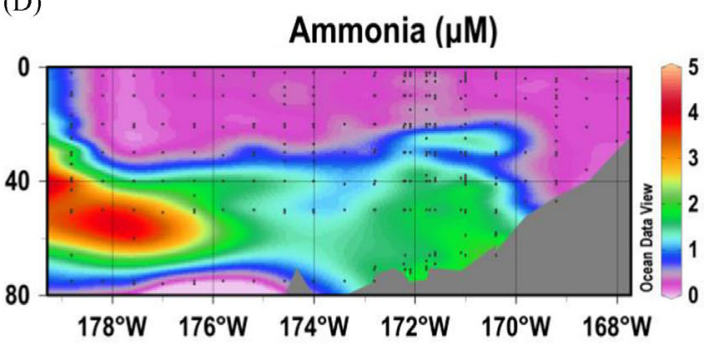

Fig. 7. Vertical sections of (A) phosphate, (B) silicate, (C) nitrate and (D) ammonia (all expressed in $\mu \mathrm{M}$ ) along the MN line. 
(A)

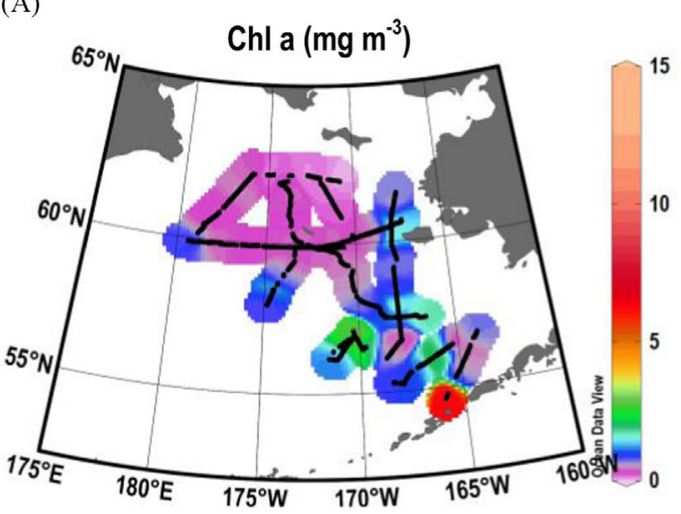

(C)

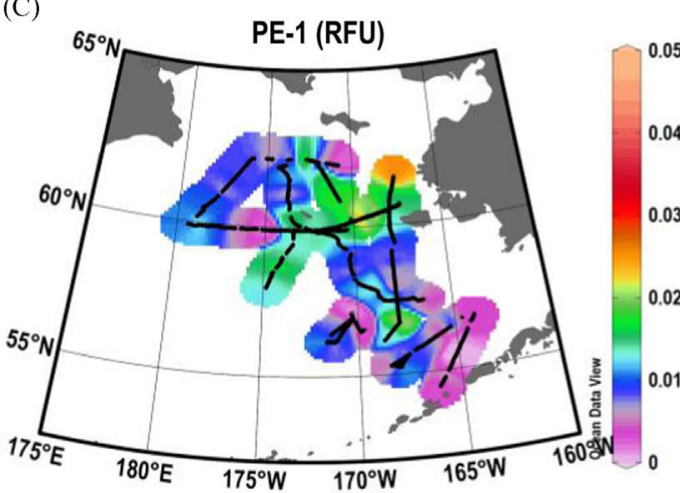

(E)

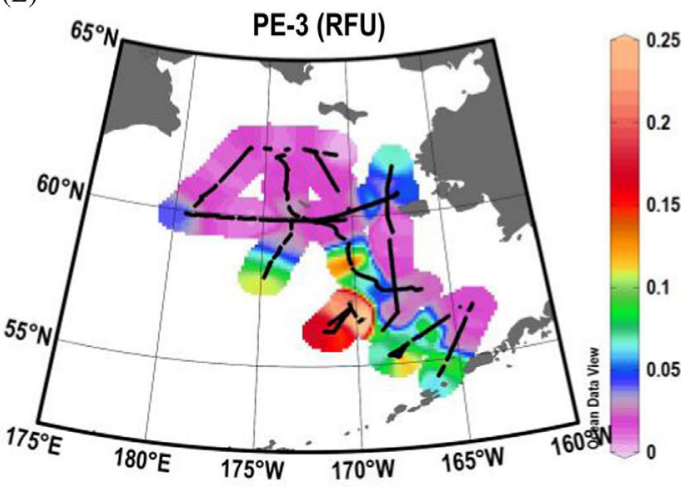

(B)

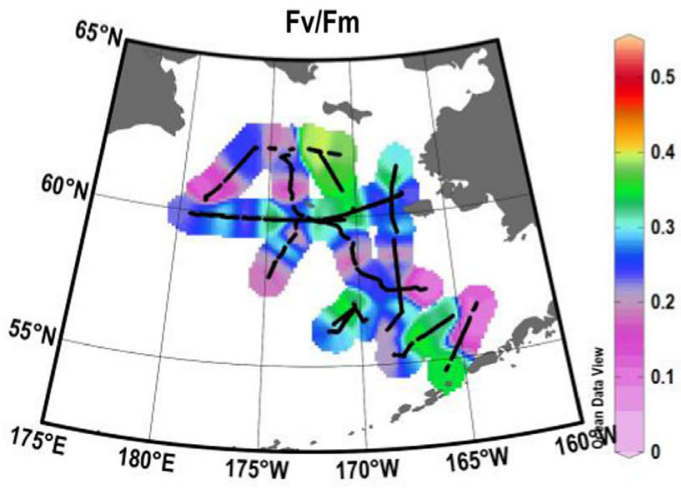

(D)

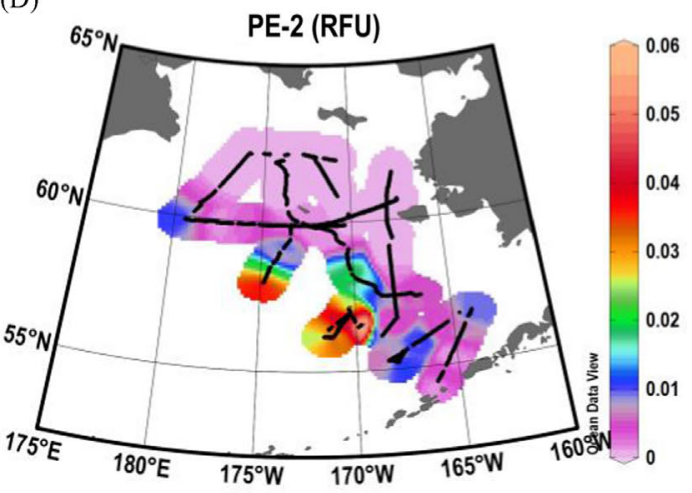

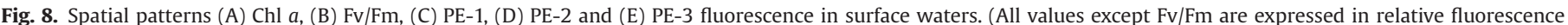
units, RFU.)

Chl $a$ was observed in the southern outer shelf (SOS), in the low salinity NIS and the NMS regions, and in the region around PB. Fv/Fm (Fig. 8B), showed photo-physiologically active phytoplankton in the NIS and Alaskan Peninsula (AKP). Elsewhere over the entire shelf, including in the Green Belt, Fv/Fm values were low indicating that phytoplankton populations in the surface waters of the eastern Bering Sea shelf and offshore were stressed.

Of the three phycobilipigment types recorded by the ALF (Fig. 8C and E), PE-3 pigment type associated with cryptophytes had the highest fluorescence (Fig. 8C). PE-3 fluorescence was highest in the Green Belt region and in the low salinity pool in the NIS. Similarly, PE-1 fluorescence was higher in the Green Belt and in the low salinity waters of the NIS. On the other hand, PE-2 fluorescence was remarkably low over the entire shelf, with the exception of the region around the PB islands and in the Green Belt.

At depth, the highest Chl $a$ concentrations were observed in the NIS and in the SM regions (Fig. 9A). As observed at the surface, Fv/Fm values were low throughout except in the low salinity waters in NIS and close to the PB and the Aleutian Islands (Fig. 9B). In general the distribution patterns of all three PE pigments at depth (Fig. 9C and E) mirrored the distribution patterns at the surface, but were much lower.

Along the $70 \mathrm{~m}$ isobath, Chl $a$ values were low throughout, with the exception of a subsurface maxima located at $35 \mathrm{~m}$ above the Cold Pool (Fig 10A). High Fv/Fm values were coincident with the location of the subsurface $\mathrm{Chl} a$ maximum between 60.5 and $61.5^{\circ} \mathrm{N}$ (Fig. 10B). PE-1 fluorescence values were very low throughout the section although comparatively higher values were observed at the surface (Fig.10C). Both PE-2 and PE-3 fluorescence values were higher in the south. In addition however, subsurface patches of high Chl a were recorded around $61^{\circ} \mathrm{N}$ (Fig. 10D and E).

The cross-shelf MN section showed only one large region of high Chl $a$ biomass at around $35 \mathrm{~m}$ in the middle shelf straddling the upper end of the Cold Pool. Other than that, phytoplankton biomass in the upper $20 \mathrm{~m}$ was very low (Fig. 11A). Offshore, 

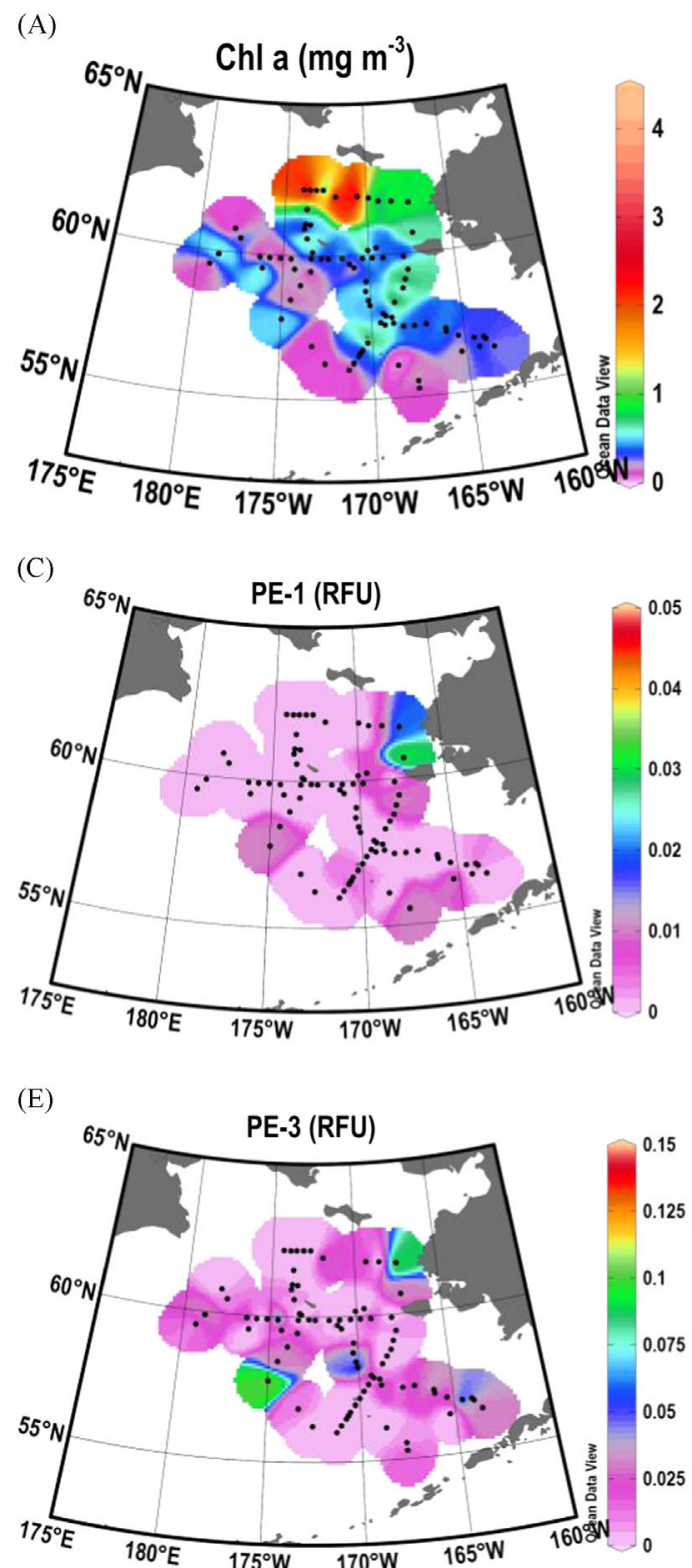
s.
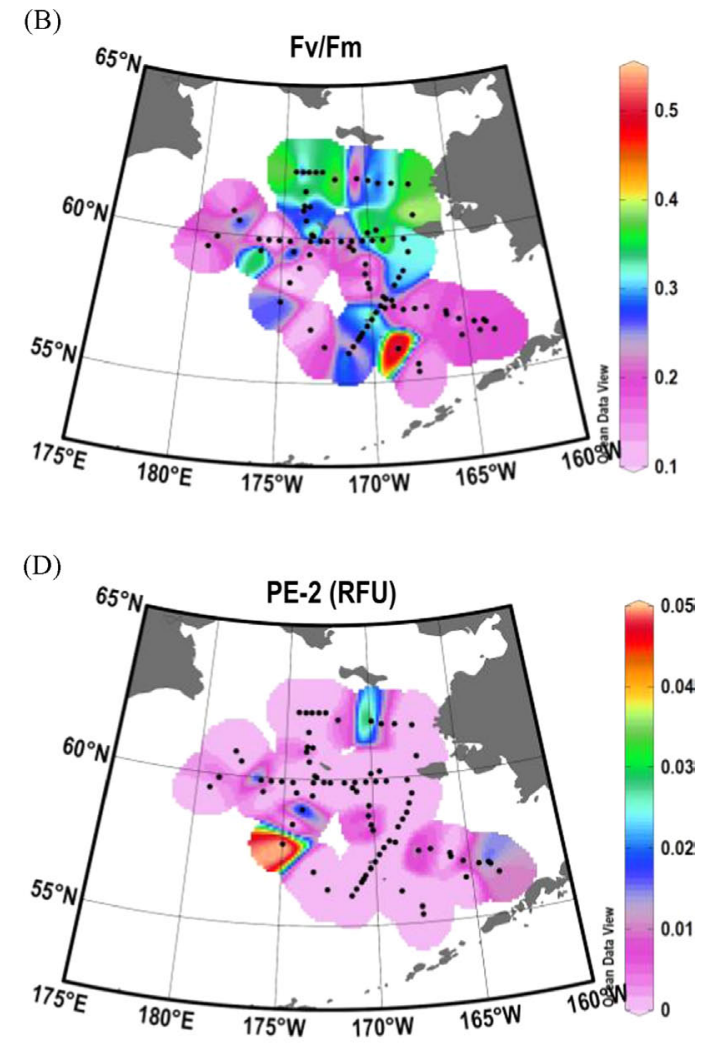

\section{.}

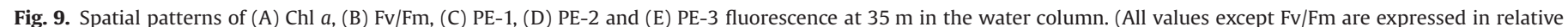
fluorescence units, RFU.)

moderately high Chl $a$ was seen at the surface and at about $35 \mathrm{~m}$. Variable fluorescence values were low along this entire section except for the higher values in the low salinity waters of the inner shelf (Fig. 11B) where PE-1 fluorescence was also high (Fig. 11C). Highest PE-2 values were recorded at the subsurface $(40 \mathrm{~m})$ above the Cold Pool and coincident with the high Chl $a$ fluorescence (Fig. 11D). PE-3 fluorescence distribution patterns along the MN line (Fig. 11E) resembled in part the distribution patterns of Chl $a$ fluorescence with the exception of a surface high in the inner shelf.

\subsection{CHEMTAX based phytoplankton groups}

CHEMTAX analyses of marker pigments showed a very mixed population of phytoplankton in the upper stratified layer (Fig. 12A). Offshore, haptophytes were significant components of the offshore phytoplankton population followed by cryptophytes and prasinophytes. The Green Belt was dominated by these three groups. These observations are consistent with the high PE-3 fluorescence values recorded in the Green Belt. Diatoms were highest in the NMS region and near the Aleutian Island chain, but in the low salinity waters of the NMS and SM, haptophytes were significant.

In contrast, at depth $(35 \mathrm{~m})$, diatoms accounted for over $90 \%$ of the population of the northern inner and middle shelves, but in the northern offshore region (OSN), haptophytes made up for a sizeable proportion of the population (Fig. 12B). The southern middle shelf was made up of a mixed population of cryptophytes, prasinophytes and diatoms.

The results of the spatial distribution patterns of the major phytoplankton groups based on CHEMTAX analysis of the pigment data (Fig. 12A and B) mirror the patterns of phytoplankton groups determined from the microscopic data (Fig 13A and F). Both centric and pennate diatoms were highest $\left(1.6 \times 10^{4}\right.$ and $1 \times 10^{3}$ cells $1^{-1}$, respectively) at depth in the NMS and SM regions where Chl a concentrations were low (Fig 13A and B), whereas the haptophyte, Phaeocystis pouchettii and cryptophytes were highest $\left(1.3 \times 10^{4}\right.$ and $4.2 \times 10^{3}$ cells $1^{-1}$, respectively) in the Green Belt 
(A)

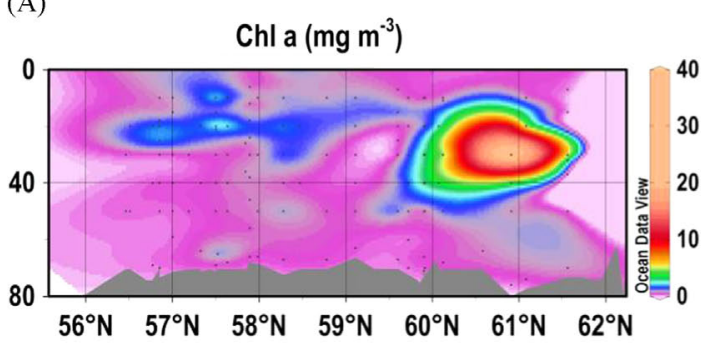

(C)

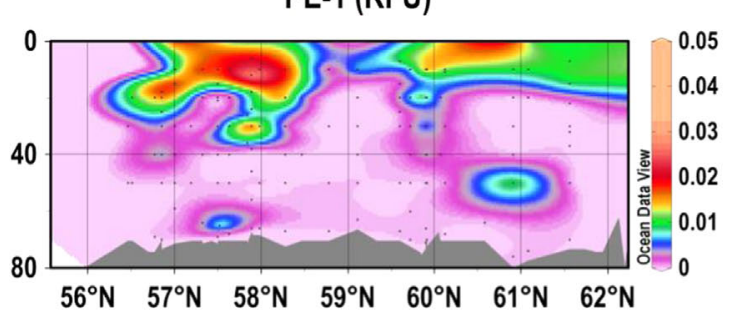

(E)

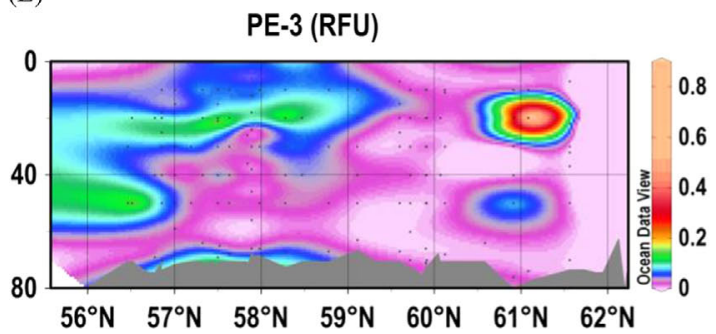

(B)

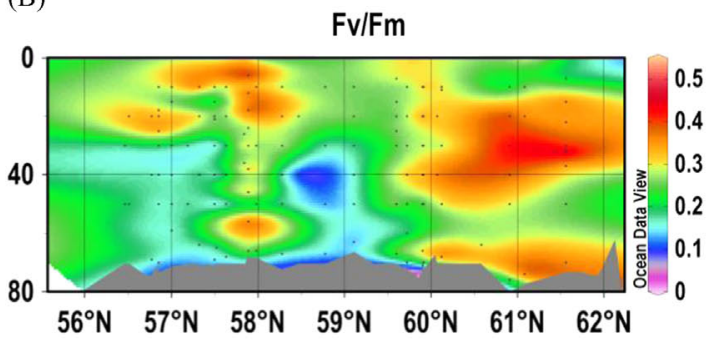

(D)

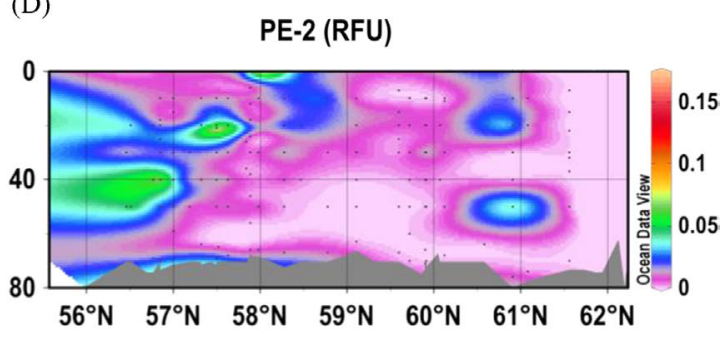

Fig. 10. Vertical sections of (A) Chl $a$, (B) Fv/Fm, (C) PE-1, (D) PE-2 and (E) PE-3 fluorescence along the $70 \mathrm{~m}$ isobath.

(A)

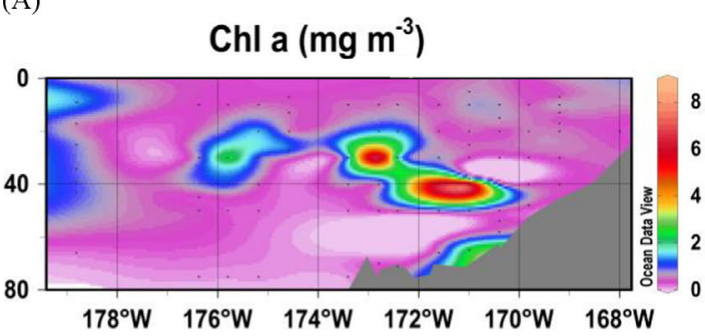

(C)

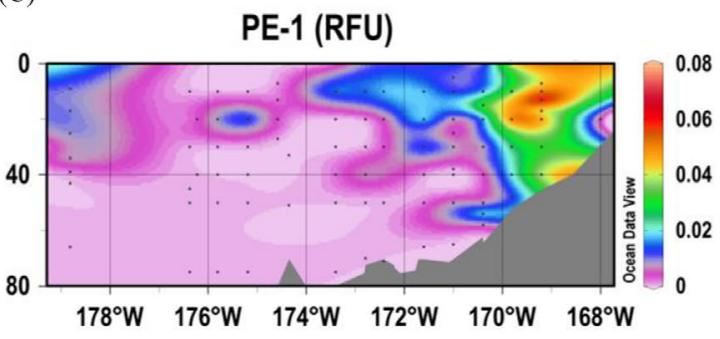

(E)

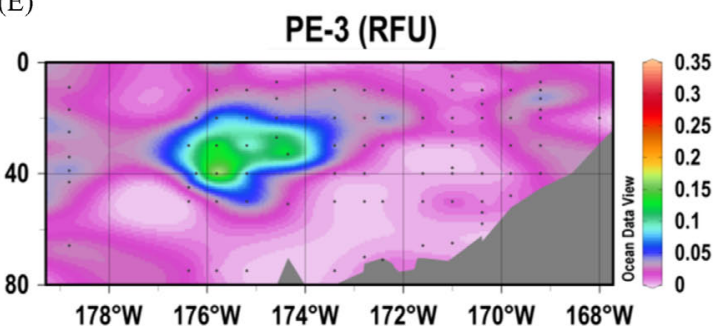

(B)

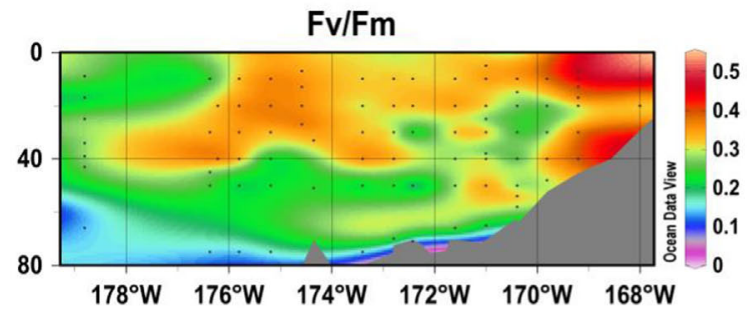

(D)

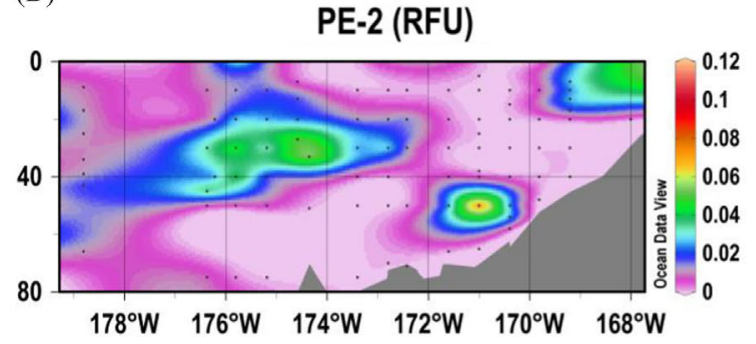

Fig. 11. Vertical sections of (A) Chl $a$, (B) Fv/Fm, (C) PE-1, (D) PE-2 and (E) PE-3 fluorescence along the MN line. 

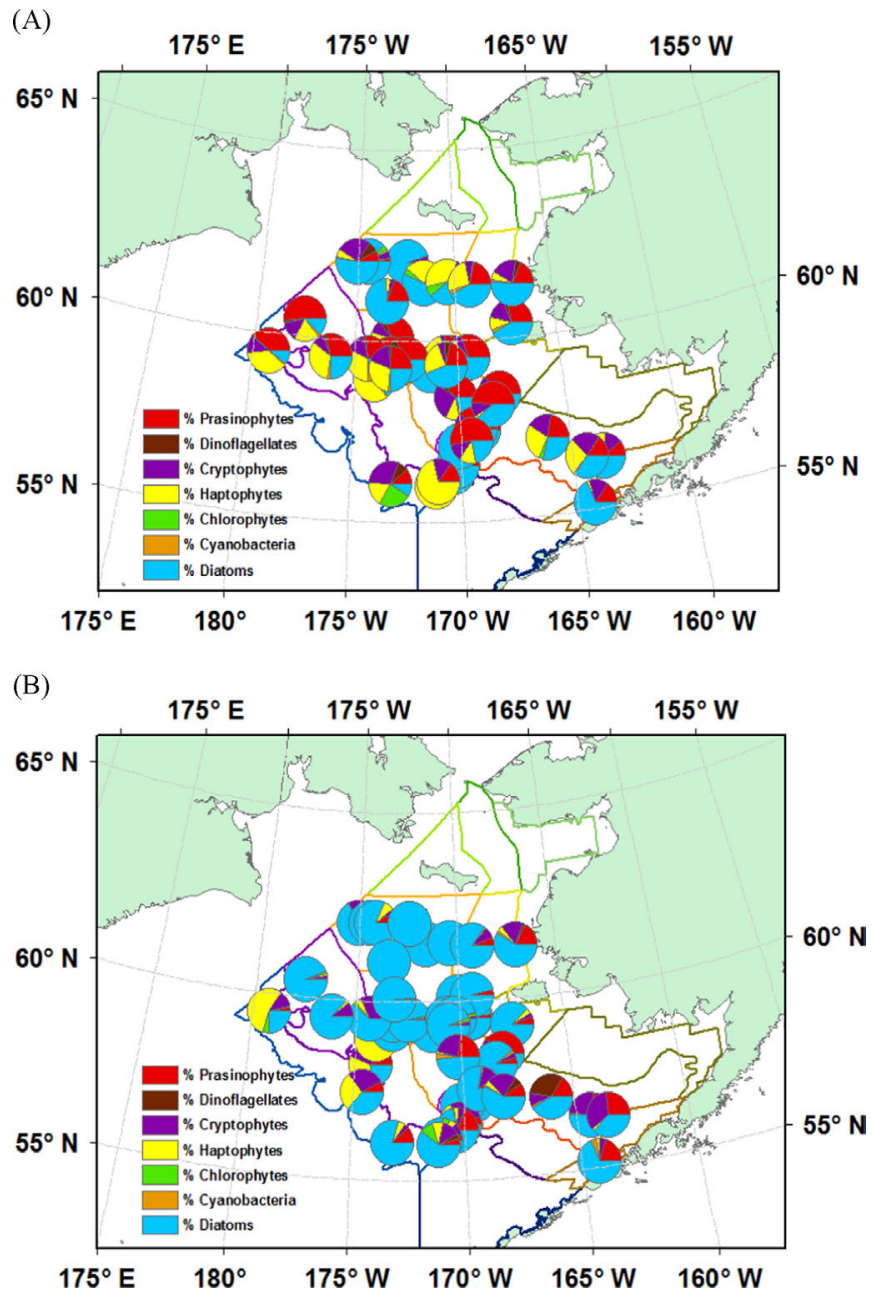

Fig. 12. Spatial patterns of HPLC/CHEMTAX derived groups of phytoplankton at (A) the surface and (B) $35 \mathrm{~m}$ in the water column over the study area.

around PB, OS and OSS (Fig. 13C and D). Counts of both the pigmented and heterotrophic dinoflagellates were low $(<2.2 \times$ $10^{3}$ and $0.75 \times 10^{2}$ cells $^{-1}$ ) throughout the southeastern Bering Sea (Fig. 13E and F).

Along the N-S $70 \mathrm{~m}$ isobath, diatom concentrations were low throughout the surface layers (Fig. 14A) but at the subsurface, a diatom-rich patch with $\mathrm{Chl} a$ concentrations of about $15 \mathrm{mg} \mathrm{m}^{-3}$ was observed around $30-35 \mathrm{~m}$ located prominently above the Cold Pool between 58.3 and $62.3^{\circ} \mathrm{N}$. In contrast, cryptophytes with Chl $a$ concentrations of about $0.5 \mathrm{mg} \mathrm{m}^{-3}$ were seen just below the surface in the southern part of the transect between 56 and $59^{\circ} \mathrm{N}$ (Fig. 14B). Haptophytes were present all along the transect except between 57 and $59.5^{\circ} \mathrm{N}$ where prasinophytes dominated (Fig. 14C and D). The highest biomass of dinoflagellates was located to the south (Fig. 14E) of the transect where cryptophytes were also present, whereas the biomass of chlorophytes although low mimicked that of diatom where their maximum biomass at depth coincided with depths where the highest biomass of diatoms was measured.

The MN cross-shelf section of phytoplankton groups shows that the high Chl $a$ patch recorded by the ALF (Fig. 11A) comprised mainly of diatoms (Fig. 15A). Elsewhere along this transect diatom concentrations were very low, in particular at the surface. Cryptophytes and haptophytes accounted for the second largest fraction of total phytoplankton biomass (Fig. 15B and C). Although their biomass was not high, cryptophytes were seen mainly offshore just above the Cold Pool. Concentrations of haptophytes were also high offshore but confined to a narrow band to the east. Prasinophytes were uniformly distributed in the upper $25 \mathrm{~m}$ along the MN section but their concentrations were low throughout (Fig. 15D). The biomass of dinoflagellates was highest offshore and at depth (Fig. 15E), whereas the highest biomass of chlorophytes (Fig. 15F) was coincident with that of the diatom patch (Fig. 15A).

\subsection{Phytoplankton species counts and community structure}

Phytoplankton species identified microscopically from samples collected from 2 depths and at 27 stations are listed in Table 1. These stations cover a broad region of the eastern Bering Sea shelf. The sinking phytoplankton bloom located above the Cold Pool was dominated by the centric diatoms Chaetoceros socialis (0.4-

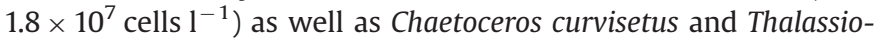
sira nordenskioeldii. These three species formed resting spores as they settled out of the shallow photic zone. A developing bloom of Leptocylindrus danicus and Porosira glacialis was observed in the NOS, NMS and SM regions where low salinity waters prevailed. Pennate diatoms such as Pseudo-nitzschia spp., Thalassionema nitzschoides and Fragilariopsis spp. were also observed in the SM and NMS regions in smaller numbers $\left(<150\right.$ cells $\left.1^{-1}\right)$ at the

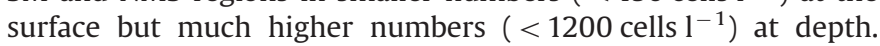
In the inner shelf region, the chrysophyte Dinobryon balticum was observed in greater numbers. In the Green Belt, region the haptophyte $P$. pouchetii and cryptophytes dominated, confirming results from CHEMTAX and the ALF (for cryptophytes). Cryptophyte numbers were highest $\left(0.6-1.9 \times 10^{6} 1^{-1}\right)$ in the shelf break region as well as near the $\mathrm{PB}$ island once again consistent with the HPLC and ALF observations.

\subsection{Inorganic nutrients and dissolved iron amendment experiments}

The results of the inorganic nutrients and the dissolved iron amendment experiments are presented in Fig. 16A and B. Summertime phytoplankton from the Bering Sea shelf clearly responded positively (one way $t$-test, $p<0.001$ ) to inorganic $\mathrm{NO}_{3}$ as evident from the over 3-fold increase in Chl $a 72 \mathrm{~h}$ after the amendment. On the other hand, no increase in Chl $a$ but a significant decrease (one way t-test, $p<0.01$ ) was observed in the incubation bags amended with inorganic $\mathrm{PO}_{4}$ (Fig. 16A).

At the outer shelf station, a significant increase in Chl $a$ concentrations above that recorded for the controls was observed (one-way ANOVA, $p<0.01$ ) in samples amended with both dissolved iron and inorganic $\mathrm{NO}_{3}$, but the increase was clearly significantly higher (one-way ANOVA, $p<0.001$ ) in the former indicating the importance of dissolved iron as a regulator of phytoplankton growth offshore (Fig. 16B).

\section{Discussion}

Hydrological and chemical measurements revealed the highly stratified nature of the Bering Sea during the summer of 2008, which would have prevented nutrient replenishment of the euphotic zone. As a consequence phytoplankton biomass levels were low over the entire eastern Bering Sea shelf on account of inorganic nitrate limitation consistent with our nutrient amendment experiment at the on-shelf station. There were three exceptions to this overall picture, the first was in the NIS where moderately high Chl $a\left(1-1.5 \mathrm{mg} \mathrm{m}^{-3}\right)$ was associated with low salinity and low temperature, possibly from recent sea-ice melt and/or river discharge. Near to the coast, the well mixed lowsalinity waters were rich in CDOM (Naik et al., 2010) suggesting their riverine origin and also, rich in PE-1 and PE-2 suggesting an increased presence of cyanophytes, perhaps Synechococcus spp., 
(A)

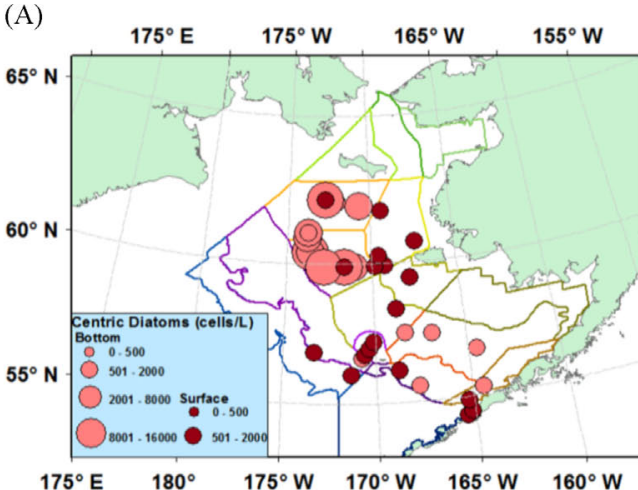

(C)

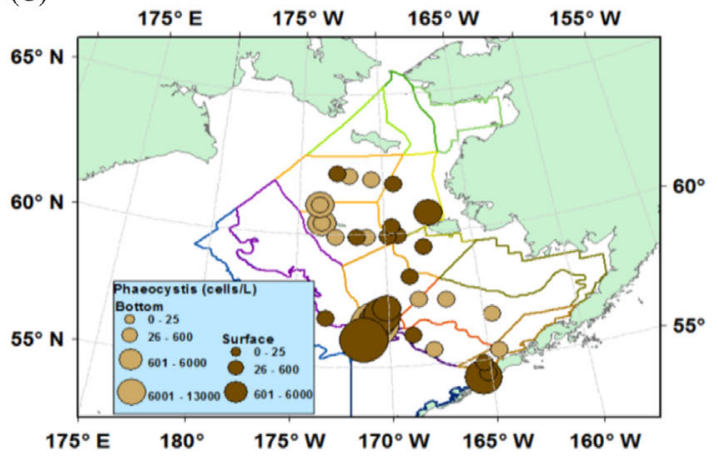

(E)

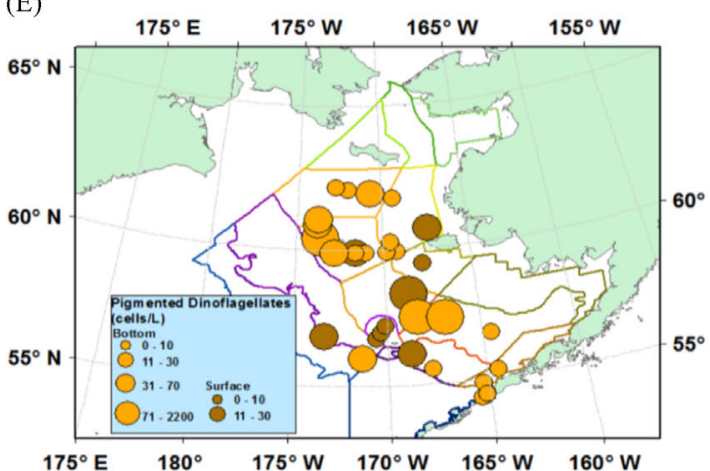
$55^{\circ} \mathrm{N}$ $55^{\circ}$

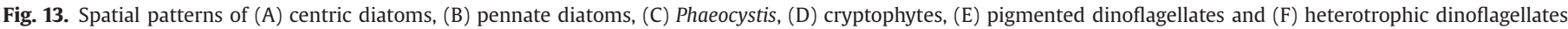
determined microscopically in samples from the surface and from the deep chlorophyll maxima (bottom). All values have been expressed as cells $\mathrm{I}^{-1}$.

which we did not enumerate in this study. Although river discharge into the Bering Sea is associated with moderate nutrient concentrations (Guo et al., 2004), its influence offshore on phytoplankton biomass could be important in summer, when the inner shelf waters are highly nutrient deficient. Away from the coast, the low salinity waters were confined to an isolated cold patch, suggesting that the origin of this water was possibly from seaice melt. Moderately high phytoplankton Chl $a$ and cell counts associated with this entrapped water parcel were likely the result of enhanced stability afforded by these waters to phytoplankton allowing them to remain in the upper well lit water column. Fv/Fm values recorded in these waters were quite high, evidence that phytoplankton within this water parcel were photosynthetically active, consistent with observations of higher growth rates observed by Stoecker et al. (this issue). One possibility is that phytoplankton were benefiting from potentially elevated levels of iron and nutrients known to be released during sea-ice melt back (Aguilar-Islas et al., 2008). A little further offshore the haptophytes, $P$. pouchetii and some cryptophytes made up for a large fraction of the total Chl $a$ biomass, possibly because these species were able
(B) $60^{\circ} \mathrm{N}$ $\left(55^{\circ}\right.$
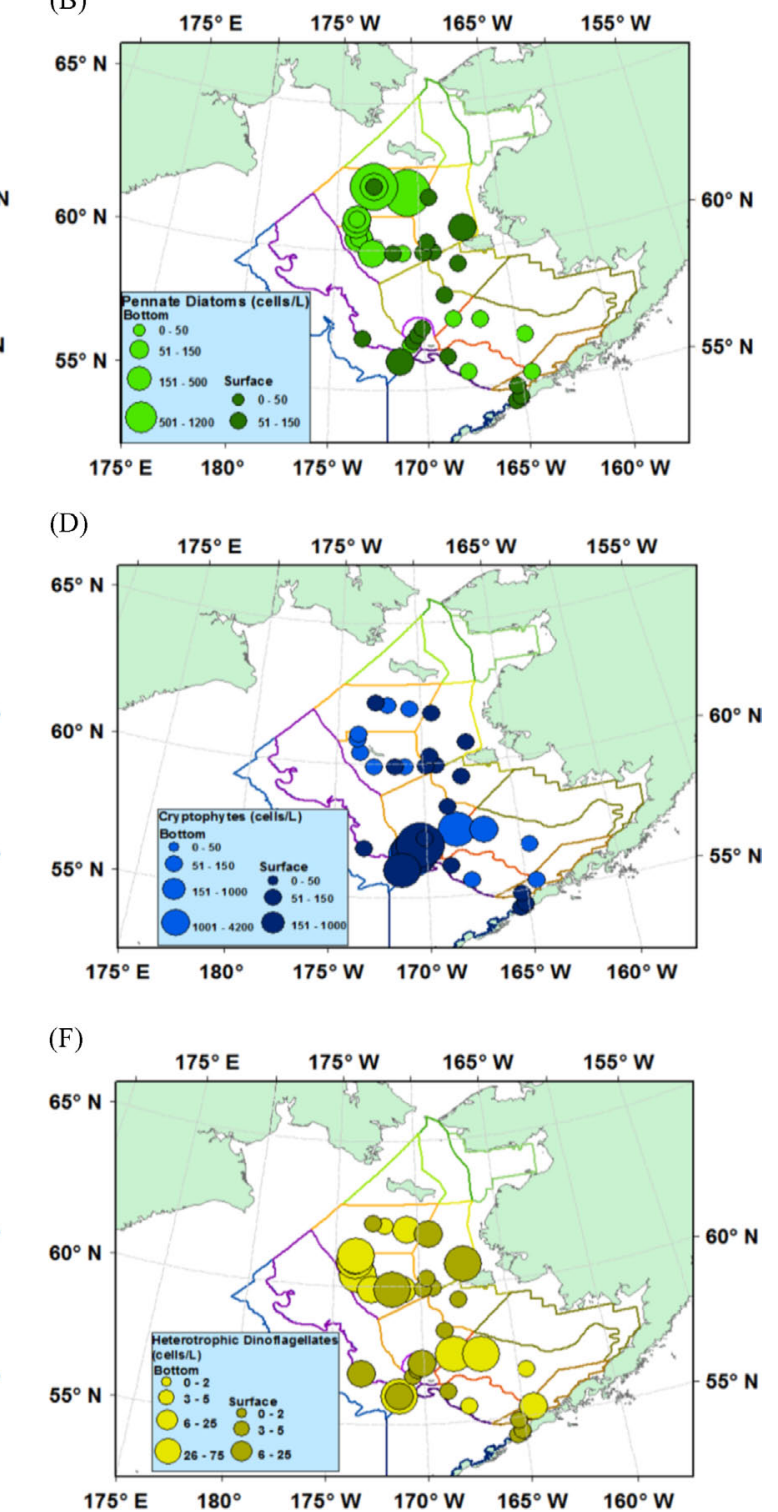

to function better under the low nutrient conditions at the sea surface or they (in particular $P$. pouchetii) were not the preferred food source for micrograzers.

The other two regions where phytoplankton concentrations were moderately higher than elsewhere on the shelf were the $\mathrm{PB}$, the Alaskan Peninsula (AKP) and the SMS, where there was evidence of cross-shelf advection of nutrients. As is typical in summer, the entire eastern Bering Sea shelf resembled a classical nitrate-limited, ironreplete system in which phytoplankton can be easily stimulated by an influx of new nutrients (Aguilar-Islas et al., 2007). This was evident from the low Fv/Fm over the entire southern and middle shelf region as well as from our on-board nutrient amendment experiments with shelf waters where a $>3$-fold increase in Chl $a$ was observed within 3 days of inorganic NO3 $(2.7 \mu \mathrm{M})$ additions (Fig. 16A). Offshore, particularly in the northern outer shelf (NOS) region, although inorganic $\mathrm{NO}_{3}$ concentrations were not limiting $\left(\mathrm{NO}_{3} \sim 3.5 \mu \mathrm{M}\right)$, Chl a concentrations were very low possibly due to iron limitation. The low Fv/Fm values recorded suggested that these were high nutrient low chlorophyll (HNLC) waters, in which phytoplankton photosynthesis and growth were iron limited. 
(A)

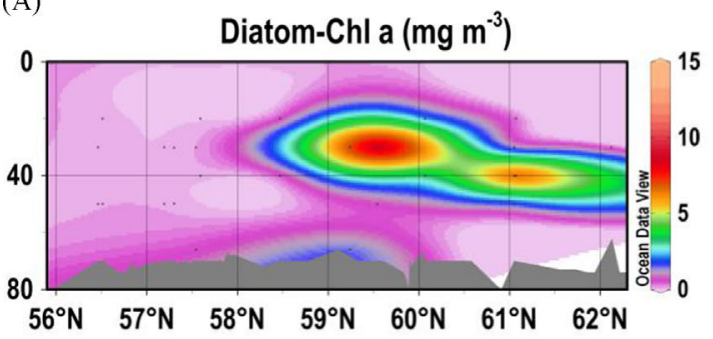

(C)

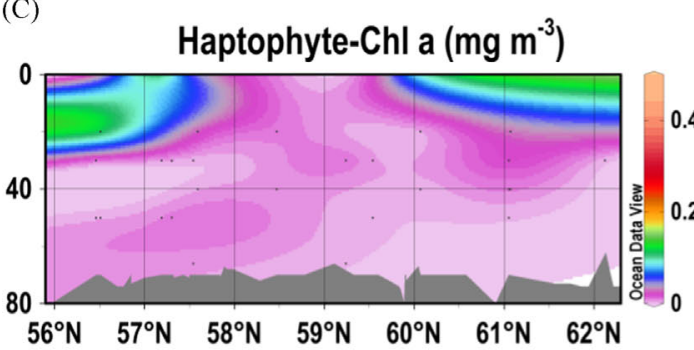

(E)

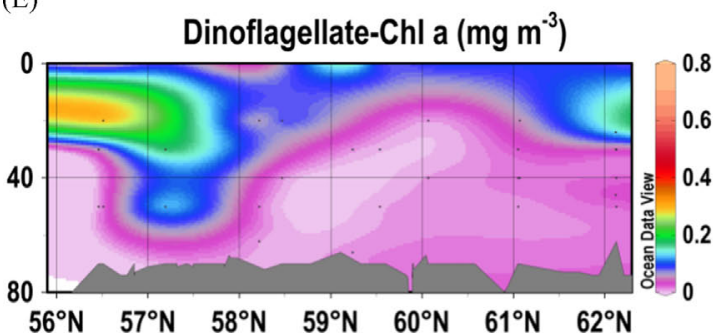

(B)

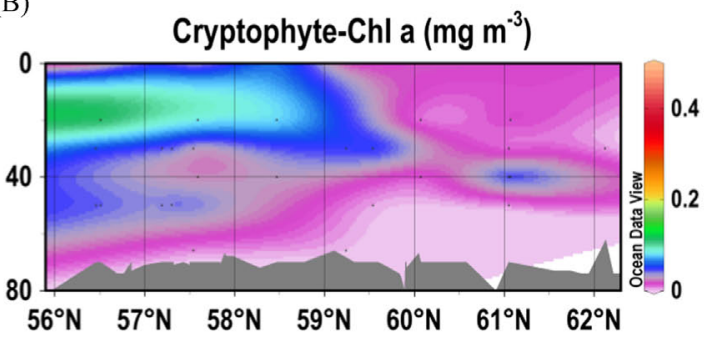

(D)

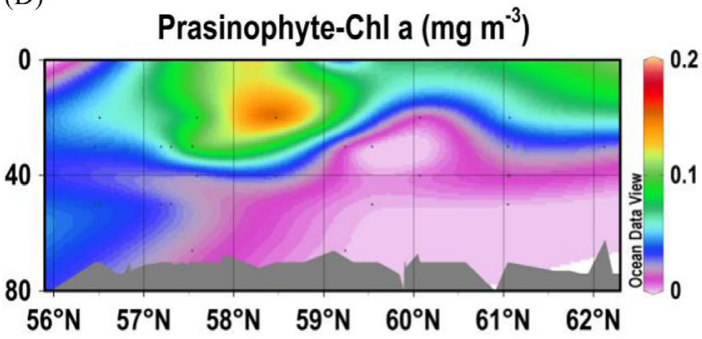

(F)

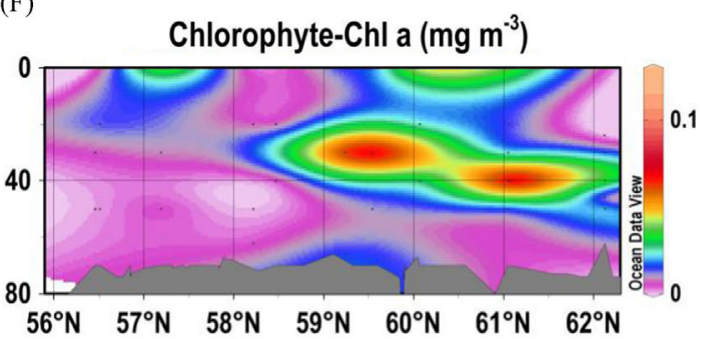

Fig. 14. Vertical sections of HPLC/CHEMTAX derived biomass attributable to (A) diatoms, (B) cryptophytes, (C) haptophytes, (D) prasinophytes, (E) dinoflagellates and $(\mathrm{F})$ chlorophytes along the $70 \mathrm{~m}$ isobath.

(A)

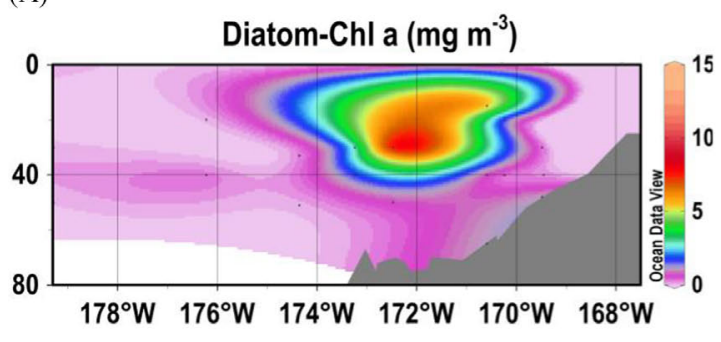

(C)

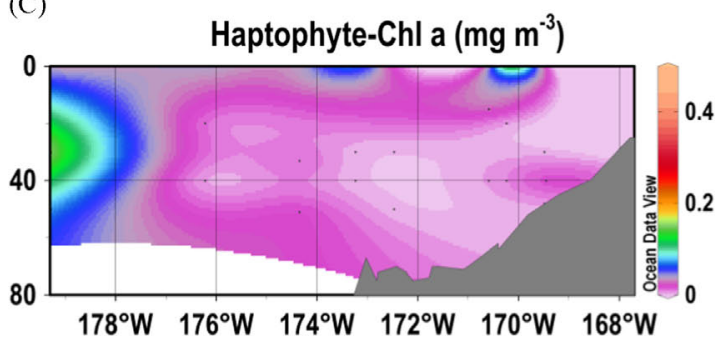

(E)

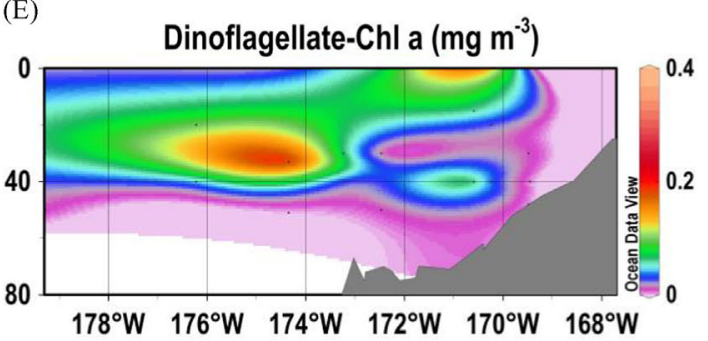

(B)

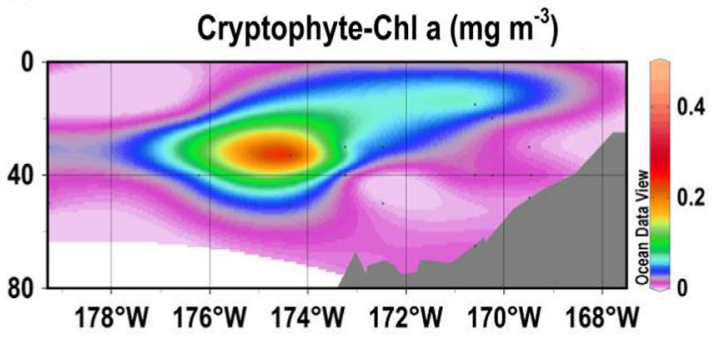

(D)

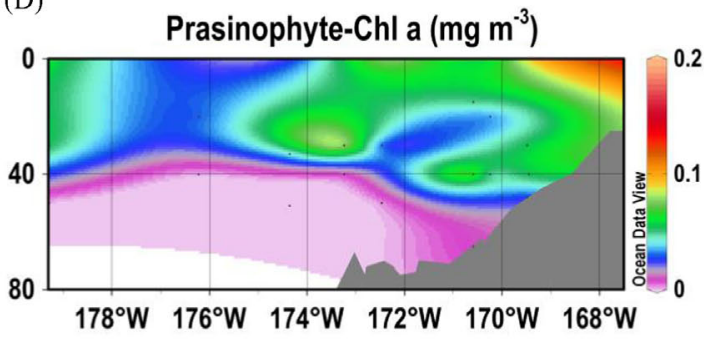

(F)

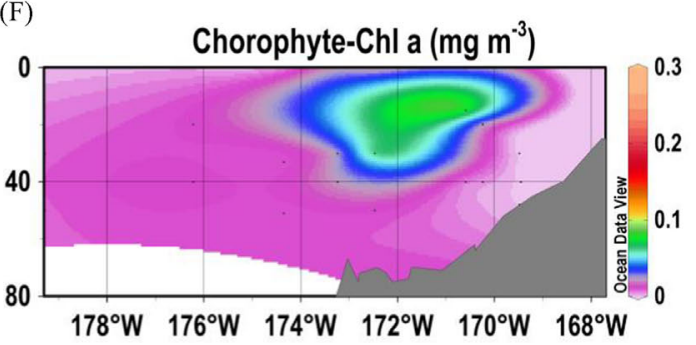

Fig. 15. Vertical sections of HPLC/CHEMTAX derived biomass attributable to (A) diatoms, (B) cryptophytes, (C) haptophytes, (D) prasinophytes, (E) dinoflagellates and $(\mathrm{F})$ chlorophytes along the MN line. 
Table 1

List of phytoplankton species observed in the eastern Bering Sea during the summer of 2008 .

\section{Centric diatoms \\ Attheya septentrionalis \\ Bacterosira sp. \\ Bacterosira bathyomphala \\ Biddulphia sp. \\ Chaetoceros compressus \\ C. concavicornis \\ C. constrictus \\ C. convolutus \\ C. curvisetus \\ C. laciniosus \\ C. septentrionalis \\ C. socialis \\ C. subtilis var. abnormis \\ Chaetoceros spp. \\ Corethron criophilum \\ Coscinodiscus sp. \\ Lauderia spp. \\ Leptocylindrus danicus \\ Melosira sp. \\ Paralia sulcata \\ Porosira glacialis \\ Proboscia alata \\ Rhizosolenia hebetata var semispina \\ T. anguste-lineata \\ T. nordenskioeldii \\ Thalassiosira spp. \\ Unidentified centric diatoms \\ Pennate diatoms \\ Fragilariopsis sp. \\ Gyrosigma fasciola \\ Navicula cf bicapitata \\ Navicula cf distans \\ Navicula sp. \\ Navicula sp. \\ Nitzschia closterium \\ Pleurosigma sp. \\ Pseudo-nitzschia spp. \\ Thalassionema nitzschoides \\ Tropidoneis sp. \\ Unidentified pennate diatom}

Heterotrophic dinoflagellates

Gyrodinium spp.

Protoperidinium bipes

Protoperidinium spp.

Torodinium sp.

Unidentified heterotrophic dinoflagellates

Phototrophic dinoflagellates

Amphidinium sp.

Dinophysis acuta

Dinophysis rotundata

Gymnodinium spp.

Heterocapsa triquetra

Oxytoxum sp.

Prorocentrum minimum

Protoperidinium minuscula

Unidentified dinoflagellate

\section{Cryptophytes}

Unidentified

Chrysophyte

Dinobryon balticum

Euglenophyte

Eutreptia sp.

Haptophytes

Phaeocystis pouchetii

\section{Silicoflagellate}

Dictyocha speculum

Mesodinium sp.

Unidentified coccoids

Unidentified phytoflagellates

Unidentified cyanobacterial filaments

cf. Tribonema sp.

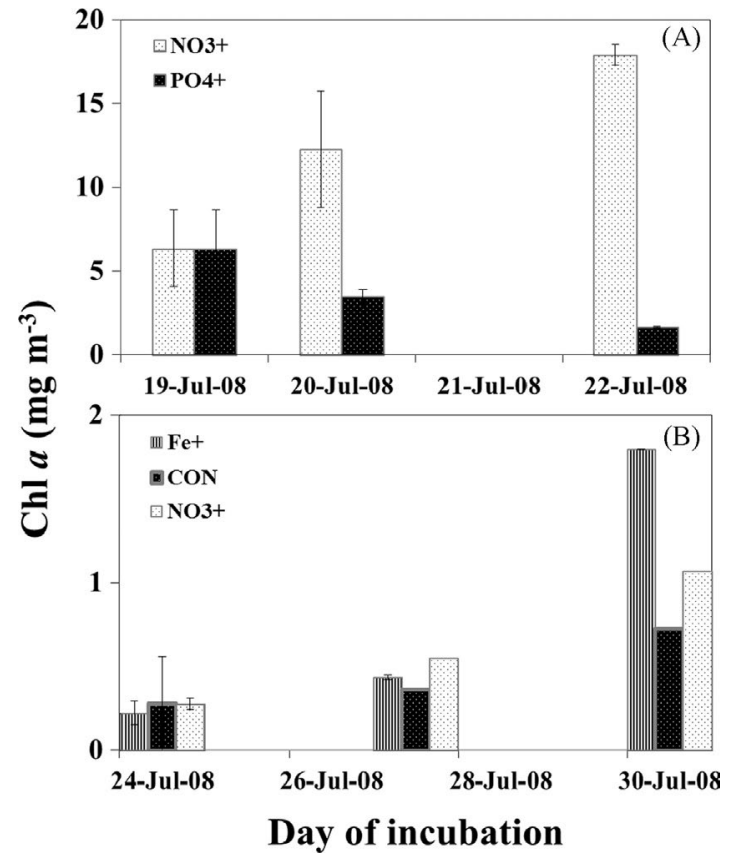

Fig. 16. Results of inorganic nutrient and dissolved iron experiments showing changes in Chl $a$ at (A) on shelf station NP-11 and (B) at the outer shelf station St. P14-4.

Dissolved iron amendment experiments (Fig. 16B) revealed an 8-fold increase in Chl $a$ by Day 6 consistent with the previous suggestions (Aguilar-Islas et al., 2007) of iron-limitation in the outer shelf waters of the Bering Sea. No such increase was observed in incubation bags amended with inorganic $\mathrm{NO}_{3}$.

Diatoms, haptophytes, cryptophytes and prasinophytes made up a large portion of the population at the surface, but haptophytes were conspicuously absent at depth. They were also absent at the surface around $\mathrm{PB}$, where diatoms dominated in all possibility due to increased sedimentary iron mobilization from the shallow shelf (Aguilar-Islas, et al., 2007). Notably Fv/Fm values and phytoplankton growth rates were higher here (Stoecker et al., this issue).

Chlorophyll $a$ concentrations both at the surface and at depth were highest in the Green Belt which extended from across the entire shelf break region and into the off-shelf north (OSN) regions in association with the north-westward moving Bering Shelf current (Wang et al., 2012). Several studies (Mizobata and Saitoh, 2004; Okkonen et al., 2004) have shown that the high biomass of the Green Belt is sustained by eddies that promote cross shelf advective mixing of waters from the offshore region into the outer shelf domains. In summer, in particular, eddies tend to propagate north-westward along the shelf edge. As they are anticyclonic (Mizobata and Saitoh, 2004; Okkonen et al., 2004) they carry with them nutrient-rich upwelled water around their periphery (Mizobata et al., 2006). When cross-shelf advection due to eddies is strong, it can lead to an increase in the width of the Green Belt (Okkonen et al., 2004). Microscopic and pigment measurements, indicate the overall dominance of $P$. pouchetii in the Green Belt observations similar to those of Springer et al. (1996) and Suzuki et al. (2002). Goering and Iverson (1981) and Flint et al. (2002) suggest that the dominance of $P$. pouchetii in the outer shelf and shelf-edge region is the result of a top-down effect in which the abundance of diatoms is controlled by preferential grazing on diatoms by herbivorous mesozooplankton. Primary productivity in the Green Belt was extremely high during the summer of 2008 (Lomas et al., 2012) but concomitant export fluxes measured using floating sediment traps (Moran et al., 2012) indicated low e-ratios 
in the Green Belt as compared to the mid-shelf region. The role of $P$. pouchetii in the primary production budget and food web of the Green Belt thus remains unclear. It has been suggested that $P$. pouchetii blooms might support a greater development of microbial food webs and nutrient recycling. In general, gelatinous colonies of Phaeocystis spp. are not efficiently grazed by zooplankton and have slow sinking rates, (Springer et al., 1996; Nejstgaard et al., 2007). By providing substrates for the development of bacteria and heterotrophic nanoplankton, their major contribution would be sustenance of an active microbial food web in the shelf break region of the Bering Sea.

The Cold Pool in the middle shelf during our study and the warmer surface layer contributed to the development of a strong pycnocline that separated a pool of nutrient-rich water at depth from the otherwise nutrient depleted surface waters above.

In summer the layer below the pycnocline can become an important source of nutrients when they are introduced into surface shelf waters by post-spring bloom storms (Sambrotto et al., 1986; Stabeno et al., 2002) or by frontal processes (Kachel et al., 2002). Summer concentrations of nutrients within this pool depend on nutrient utilization especially at depth, when the spring bloom begins to form (Stockwell et al., 2001). A nutrientdepleted subsurface pool can result when considerable new production occurs at depth during the spring (Stockwell et al., 2001). Nutrient distribution patterns along the $70 \mathrm{~m}$ isobath showed that there was substantial nutrient depletion at depth between $58^{\circ}$ and $60^{\circ} \mathrm{N}$. North of this region, stratification resulting from the late retreat of sea-ice, coupled with an absence of strong winds, isolated the Cold Pool before nutrients could be utilized. With the freshly sinking bloom straddling its surface, it appears that the Cold Pool acts as a barrier for the sinking material, preventing it from reaching the bottom where it can be available for benthic organisms. During cold summers devoid of energetic storms like the summer that we encountered, we hypothesize that the Cold Pool reduces carbon export to depth, instead making it more accessible to pelagic organisms rather than benthic organisms. This idea is consistent with the observations of Coyle et al. (2011), Hunt et al. (2008), Lomas et al. (2012) and Stabeno et al. (2012a,b) who cite an increase in numbers of the largest copepod Calanus marshallae (a vital food source for commercially important fisheries of the Bering Sea) in the middle shelf during the cold years of 2008 and 2009 that followed the warm spell in the Bering Sea.

Based on the hydrographic and the chemical measurements, we suggest that the Cold Pool together with freshwater from sea-ice melt and from coastal riverine discharge together, obstruct cross shelf advection of offshore water on to the shelf, effectively isolating surface waters of the northern Bering Sea shelf, and preventing replenishment with new nutrients. The paucity of nutrients in the upper layer of the two layered middle shelf waters was in all likelihood responsible for the termination of the diatom bloom. The presence of cryptophytes and chlorophytes in the sinking bloom and the relative increase in prasinophytes at the sea surface suggest a pattern of succession of phytoplankton that is consistent with a transition from colder nutrient rich waters to warmer nutrient impoverished waters (Baduini et al., 2001; Stockwell et al., 2001). In general, nutrient poor waters at the surface were associated with cryptophytes, haptophytes and prasinophytes which accounted for a significant fraction of the low phytoplankton biomass.

\section{Conclusions}

In summer, the eastern Bering Sea shelf is a classic high iron low nutrient region which is not capable of supporting active phytoplankton growth. The Green Belt in contrast was richer and its higher biomass was made up largely of $P$. pouchetii and cryptophytes whose presence could have been aided by preferential grazing on diatoms, and whose sustained growth was most likely supported by eddy-driven upwelling of new nutrients. These populations were however photo-physiologically stressed possibly due to iron limitation. In the middle shelf, diatoms which made up for a large fraction of phytoplankton in subsurface waters appeared to be remnants of the spring bloom. The presence of the sinking diatom bloom right above the Cold Pool leads us to suggest, that this hydrographic feature when present, is an impediment for the transfer of organic matter to the benthic community. We posit that if the Cold Pool is not eroded by summer storms, its major ecological role is that it serves as a conduit for the transfer of organic matter to pelagic communities.

\section{Acknowledgments}

This study is being funded by NASA grants NNX11AP28G and NNX10AP10G. We are grateful to the National Science Foundation and to the North Pacific Research Board for permission to join the BEST/BSIERP multi-disciplinary cruises. Hydrological and chemical data utilized in this study was collected by NOAA, PMEL. We are especially grateful to William Floering of the NOAA, Pacific Marine Environmental Laboratory and to Calvin Mordy of the Joint Institute for the Study of the Atmosphere, University of Washington for their help during the cruise. This is BEST-BSIERP Bering Sea Project publication number 119 and Lamont Doherty Earth Observatory, Columbia University publication number 7752.

\section{References}

Aagaard, K., Coachman, L.K., Carmack, E., 1981. On the halocline of the Arctic Ocean. Deep Sea Res. I 28, 529-545.

Aguilar-Islas, A.M., Rember, R., Mordy, C.W., Wu., J., 2008. Sea-ice-derived dissolved iron and its potential influence on the spring algal bloom in the Bering Sea. Geophys. Res. Lett. 35, L24601.

Aguilar-Islas, A.M., Hurst, M.P., Buck, K.N., Sohst, B., Smith, G.J., Lohan, M.C., Bruland, K.W., 2007. Micro- and macronutrients in the southeastern Bering Sea: insight into iron- replete and iron-depleted regimes. Progr. Oceanogr. 73, 99-126.

Baduini, C.L., Hyrenbach, K.D., Coyle, K.O., Pinchuk, A., Mendenhall, V., Hunt, G.L., 2001. Mass mortality of short-tailed shearwaters in the south-eastern Bering Sea during summer 1997. Fish. Oceanogr. 10, 117-130.

Booth, B.C., 1993. Estimating cell concentration and biomass of autotrophic plankton using microscopy. In: Kemp, P.F., Sherr, B.F., Sherr, E.B., Cole, J.J. (Eds.), Handbook of Methods in Aquatic Microbial Ecology. Lewis Publ., Boca Raton, pp. 199-205.

Broerse, A.T.C., Tyrrell, T., Young, J.R., Poulton, A.J., Merico, A., Balch, W.M., Miller, P.I., 2003. The cause of bright waters in the Bering Sea in winter. Cont. Shelf Res. 23, 1579-1596.

Chekalyuk, A., Hafez, M.A., 2008. Advanced laser fluorometry of natural aquatic environments. Limnol. Oceanogr. Methods 6, 591.

Chekalyuk, A., Hafez, M.A., 2011. Photo-physiological variability in phytoplankton chlorophyll fluorescence and assessment of chlorophyll concentration. Opt. Exp. 19, 22643-22658.

Chekalyuk, A.M., Landry, M.R., Goericke, R., Taylor, A.G., Hafez, M.A., 2012. Laser fluorescence analysis of phytoplankton across a frontal zone in the California Current ecosystem. J. Plankton Res. 34, 761-777.

Ciannelli, L., Bailey, K.M., 2005. Landscape dynamics and resulting species interactions: The cod-capelin system in the southeastern Bering Sea. Mar. Ecol. Progr. Ser. 291, 227-236.

Coachman, L.K., 1986. Circulation, water masses, and fluxes on the southeastern Bering Sea shelf. Cont. Shelf Res. 5, 23-108.

Coyle, K.O., Eisner, L.B., Mueter, F.J., Pinchuk, A.I., Janout, M.A., Cieciel, K.D., Farley, E. V., Andrews, A.G., 2011. Climate change in the southeastern Bering Sea: impacts on pollock stocks and implications for the oscillating control hypothesis. Fish. Oceanogr. 20, 139-156.

Cross, J.N., Mathis, J.T., Bates, N.R., 2012. Hydrographic controls on net community production and total organic carbon distributions in the eastern Bering Sea. Deep Sea Res. II, 98-109.

Egge, J.K., Aksnes, D.L., 1992. Silicate as regulating nutrient in phytoplankton competition. Mar. Ecol. Prog. Ser. 83, 281-289.

Flint, M.V., Sukhanova, I.N., Kopylov, A.I., Poyarkov, S.G., Whitledge, T.E., 2002. Plankton distribution associated with frontal zones in the vicinity of the Pribilof Islands. Deep Sea Res. II 49, 6069-6093. 
Goering, J.J., Iverson, R.L., 1981. Phytoplankton distribution on the southeastern Bering Sea shelf. East. Bering Sea Shelf Oceanogr. Resources 2, 933-946.

Goes, J.I., Gomes, H.R. Chekalyuk, A., Carpenter, E.J., Montoya, J.P., Coles, V.J., Yager, P.L., Berelson, W.M., Capone, D., Foster, R.A., Steinberg, D.K., Hafez, M. Influence of the Amazon River discharge on the biogeography of phytoplankton communities in the western tropical north Atlantic Ocean. Prog. Oceanogr., http://dx.doi.org/10.1016/j.pocean.2013.07.010, in press.

Gordon, L.I., Joe, C. Jennings, J., Ross, A.A., Krest, J.M., 1993. A suggested protocol for continuous flow automated analysis of seawater nutrients (phosphate, nitrate, nitrite and silicic acid) in the WOCE Hydrographic Program and the Joint Global Ocean Fluxes Study. In: WOCE Operations Manual, Vol. 3: The Observational Program, Section 3.2: WOCE Hydrographic Programme, Part 3.1.3: WHP Operations and Methods. WHP Office Report WHPO 91-1; WOCE Report No. 68/91, November 1994, Revision 1, Woods Hole, MA, USA, 52.

Guo, L., Tanaka, T., Wang, D., Tanaka, N., Murata, A., 2004. Distributions, speciation and stable isotope composition of organic matter in the southeastern Bering Sea. Mar. Chem. 91, 211-226.

Higgins, H.W., Wright, S.W., Schlüter, L., 2011. Quantitative interpretation of chemotaxonomic pigment data. In: Roy, S., Llewellyn, C.A., Johnsen, G., Egeland, E.S. (Eds.), Phytoplankton Pigments in Oceanography, Cambridge University Press, Cambridge, UK, pp. 257-301.

Hooker, S.B., Heukelem, L.V., Thomas, C.S., Claustre, H., Ras, J., Barlow, R., Sessions, H., Schluter, L., Perl, J., Trees, C., Stuart, V., Head, E., Clementson, L., Fishwick, J., Llewellyn, C., Aiken, J., 2005. The Second SeaWiFS HPLC Analysis Round Robin Experiment (SeaHARRE-2), NASA TM/2005-212785. NASA Goddard Space Flight Center, Greenbelt, MD.

Hunt, G.L., Stabeno, P.J., Strom, S., Napp, J.M., 2008. Patterns of spatial and temporal variation in the marine ecosystem of the southeastern Bering Sea, with special reference to the Pribilof Domain. Deep Sea Res. II 55, 1919-1944.

Hunt, G.L., Coyle, K.O., Eisner, L.B., Farley, E.V., Heintz, R.A., Mueter, F., Napp, J.M., Overland, J.E., Ressler, P.H., Salo, S., Stabeno, P.J., 2011. Climate impacts on eastern Bering Sea foodwebs: a synthesis of new data and an assessment of the Oscillating Control Hypothesis. ICES. J. Mar. Sci. J. Cons. 68, 1230-1243.

Kachel, N.B., Hunt Jr, G.L., Salo, S.A., Schumacher, J.D., Stabeno, P.J., Whitledge, T.E. 2002. Characteristics and variability of the inner front of the southeastern Bering Sea. Deep Sea Res. II 49, 5889-5909.

Knap, A., Michaels, A., Close, A., Ducklow, H., Dickson, A., 1994. Protocols for the Joint Global Ocean Flux Study (JGOFS) Core Measurements. JGOFS Report 19, p. 170

Kotwicki, S., Buckley, T.W., Honkalehto, T., Walters, G., 2005. Variation in the distribution of walleye pollock (Theragra chalcogramma) with temperature and implications for seasonal migration. Fish. Bull. 103, 574-587.

Ladd, C., Stabeno, P.J., 2012. Stratification on the Eastern Bering Sea shelf revisited. Deep Sea Res. II 65-70, 72-83.

Lomas, M.W., Moran, S.B., Casey, J.R., Bell, D.W., Tiahlo, M., Whitefield, J., Kelly, R.P., Mathis, J.T., Cokelet, E.D., 2012. Spatial and seasonal variability of primary production on the Eastern Bering Sea shelf. Deep Sea Res., 126-140.

MacIssac, E.A., Stockner, J.G., 1993. Enumeration of phototrophic picoplankton by autofluorescence microscopy. In: Kemp, P.F., Cole, J.J., Sherr, B.F., Sherr, E.B. (Eds.), Handbook of Methodology in Aquatic Microbial Ecology. Lewis Publishers, Boca Raton, Florida, USA, pp. 187-197.

Mackey, D.J., Higgins, H.W., Mackey, M.D., Holdsworth, D., 1998. Algal class abundances in the western equatorial Pacific: estimation from HPLC measurements of chloroplast pigments using CHEMTAX. Deep Sea Res. I 45, 1441-1468.

Mackey, M.D., Mackey, D.J., Higgins, H.W., Wright, S.W., 1996. CHEMTAX - a program for estimating class abundances from chemical markers: application to HPLC measurements of phytoplankton. Mar. Ecol. Prog. Ser. 144, 265-283.

Mizobata, K., Saitoh, S., 2004. Variability of Bering Sea eddies and primary productivity along the shelf edge during 1998-2000 using satellite multisensor remote sensing. J. Mar. Syst. 50, 101-111.

Mizobata, K., Wang, J., Saitoh, S., 2006. Eddy-induced cross-slope exchange maintaining summer high productivity of the Bering Sea shelf break. J. Geophys. Res. 111, C10017.

Moran, S.B., Lomas, M.W., Kelly, R.P., Gradinger, R., Iken, K., Mathis, J.T., 2012. Seasonal succession of net primary productivity, particulate organic carbon export, and autotrophic community composition in the eastern Bering Sea. Deep Sea Res. II 65, 84-97.

Naik, P., D'Sa, E.J., Goes, J.I., Gomes, H.R., 2010. Assessment of particulate absorption properties in the southeastern Bering Sea from in-situ and remote sensing data. J. Appl. Remote Sens. 4, 043561.

Nejstgaard, J.C., Tang, K.W., Steinke, M., Dutz, J., Koski, M., Antajan, E., Long, J.D., 2007. Zooplankton grazing on Phaeocystis: a quantitative review and future challenges. Biogeochemistry 83, 147-172.
NOAA, 2013. Fisheries of the United States of 2012. In: Lowther, A. (Ed.), National Marine Fisheries Service, Office of Science and Technology. Silver Spring, Maryland, USA, p. 129.

Okkonen, S.R., Schmidt, G.M., Cokelet, E.D., Stabeno, P.J., 2004. Satellite and hydrographic observations of the Bering Sea 'Green Belt'. Deep Sea Res. II 51, 1033-1051.

Ortiz, I., Weise, F., Greig, A., 2012. Marine Regions Boundary Data for the Bering Sea Shelf and Slope. UCAR/NCAR - EOL/Computing, Data, and Software Facility. 10.5065/D6DF6P6C

Overland, J.E., Salo, S., Adams, J.M., 1999. Salinity signature of the Pacific Decadal Oscillation. Geophys. Res. Lett. 26, 1337-1340.

Overland, J.E., Stabeno, P.J., 2004. Is the climate of the Bering Sea warming and affecting the ecosystem. Eos Trans. AGU 85, 309.

Overland, J.E., Wang, M., Wood, K.R., Percival, D.B., Bond, N.A., 2012. Recent Bering Sea warm and cold events in a 95-year context. Deep Sea Res. II 65-70, 6-13.

Rho, T., Whitledge, T.E., Goering, J.J., 2005. Interannual variations of nutrients and primary production over the southeastern Bering Sea shelf during the spring of 1997, 1998, and 1999. Oceanology 45 (376-390), 376-390.

Sambrotto, R.N., Niebauer, H.J., Goering, J.J., Iverson, R.L., 1986. Relationships among vertical mixing, nitrate uptake, and phytoplankton growth during the spring bloom in the southeast Bering Sea middle shelf. Cont. Shelf Res. 5, 161-198.

Springer, A.M., McRoy, C.P., Flint, M.V., 1996. The Bering Sea Green Belt: shelf-edge processes and ecosystem production. Fish. Oceanogr. 5, 205-223.

Stabeno, P.J., Kachel, N.B., Sullivan, M., Whitledge, T.E., 2002. Variability of physica and chemical characteristics along the 70-m isobath of the southeastern Bering Sea. Deep Sea Res. II 49, 5931-5943.

Stabeno, P.J., Bond, N.A., Salo, S.A., 2007. On the recent warming of the southeastern Bering Sea shelf. Deep-Sea Res. II 54, 2599-2618.

Stabeno, P., Napp, J., Mordy, C., Whitledge, T., 2010. Factors influencing physical structure and lower trophic levels of the eastern Bering Sea shelf in 2005: Sea-ice, tides and winds. Prog. Oceanogr. 85, 180-196.

Stabeno, P.J., Bond, N.A., Kachel, N.B., Salo, S.A., Schumacher, J.D., 2001. On the temporal variability of the physical environment over the south-eastern Bering Sea. Fish. Oceanogr. 10, 81-98.

Stabeno, P.J., Farley Jr, E.V., Kachel, N.B., Moore, S., Mordy, C.W., Napp, J.M., Overland, J.E., Pinchuk, A.I., Sigler, M.F., 2012a. A comparison of the physics of the northern and southern shelves of the eastern Bering Sea and some implications for the ecosystem. Deep Sea Res. II 65-70, 14-30.

Stabeno, P.J., Kachel, N.B., Moore, S.E., Napp, J.M., Sigler, M., Yamaguchi, A., Zerbini, A.N., 2012b. Comparison of warm and cold years on the southeastern Bering Sea shelf and some implications for the ecosystem. Deep Sea Res. Il 65-70, 31-45.

Stabeno, P.J., Overland, J.E., 2001. Bering Sea shifts toward an earlier spring transition. Eos Trans. AGU, 82; , pp. 317-321.

Stockwell, D.A., Whitledge, T.E., Zeeman, S.I., Coyle, K.O., Napp, J.M., Brodeur, R.D. Pinchuk, A.I., Hunt, G.L., 2001. Anomalous conditions in the south-eastern Bering Sea, 1997: nutrients, phytoplankton and zooplankton. Fish. Oceanogr. 10 99-116.

Stoecker, D., Weigel, A., Goes, J.I. Microzooplankton grazing in the eastern Bering Sea in summer. Deep Sea Res. II, http://dx.doi.org/10.1016/j.dsr2.2013.09.017, this issue.

Sullivan, M.E., Kachel, N.B., Mordy, C.W., Stabeno, P.J., 2008. The Pribilof Islands: temperature, salinity and nitrate during summer 2004. Deep Sea Res. II 55, $1729-1737$.

Suzuki, K, Minami, $C$, Liu, $\mathrm{H}$, Saino, $\mathrm{T}$, 2002. Temporal and spatial patterns of chemotaxonomic algal pigments in the subarctic Pacific and the Bering Sea during the early summer of 1999. Deep Sea Res. II 49, 5685-5704.

Tomas, C.R., 1997. Identifying Marine Phytoplankton. Academic Press, New York.

Van Heukelem, L., Thomas, C.S., 2001. Computer-assisted high-performance liquid chromatography method development with applications to the isolation and analysis of phytoplankton pigments. J. Chromatogr. A 910, 31-49.

Wang, M., Overland, J.E., Stabeno, P., 2012. Future climate of the Bering and Chukchi Seas projected by global climate models. Deep Sea Res. II 65-70, 46-57.

Whitledge, T.E., Reeburgh, W.S., Walsh, J.J., 1986. Seasonal inorganic nitrogen distributions and dynamics in the southeastern Bering Sea. Cont. Shelf Res. 5 109-132.

Woodgate, R.A., Aagaard, K., Weingartner, T.J., 2005. Monthly temperature, salinity, and transport variability of the Bering Strait through flow. Geophys. Res. Lett. 32, L04601.

Zhang, J., Woodgate, R., Mangiameli, S., 2012. Towards seasonal prediction of the distribution and extent of cold bottom waters on the Bering Sea shelf. Deep Sea Res. II 65-70, 58-71. 